Intracellular bacteria interfere with dendritic cell function: Role of type I

Interferon pathway

L. Gorvel, J. Textoris, R. Banchereau, A. Ben Amara, W. Tantibhedhyangkul, K. von Bargen, M.B. Ka, C. Capo, E. Ghigo, J.P. Gorvel and J.L. Mege

Supplementary Results S1: Pathway Analysis of Transcriptional Modulation of moDC by Intracellular Bacteria

Based on the functional analysis of the genes modulated by the intracellular bacteria or LPS in moDC, we extracted the identified KEGG pathways and color coded the nodes according to the modulation of gene expression after each stimulation. 


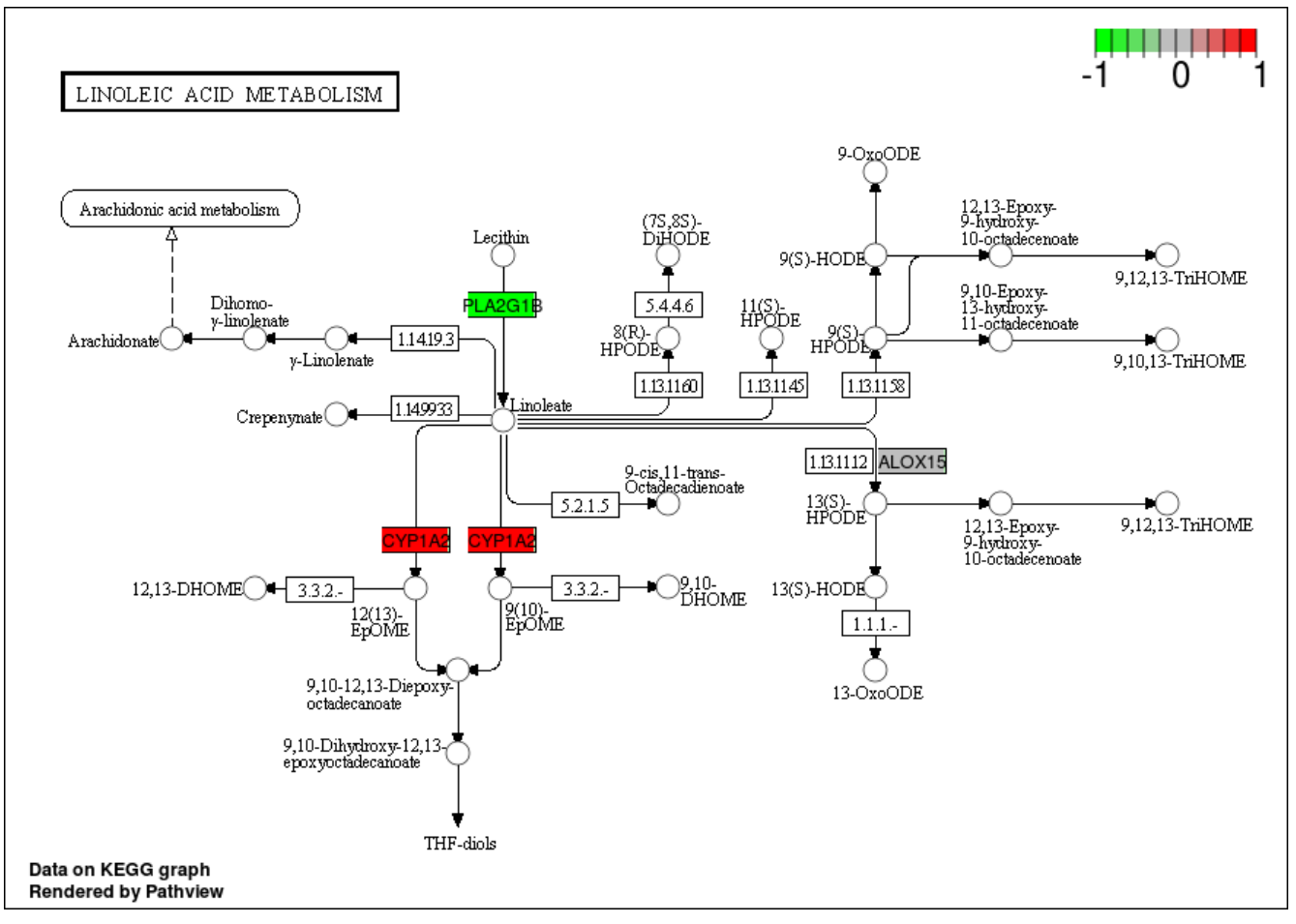

Orientia tsutsugamushi

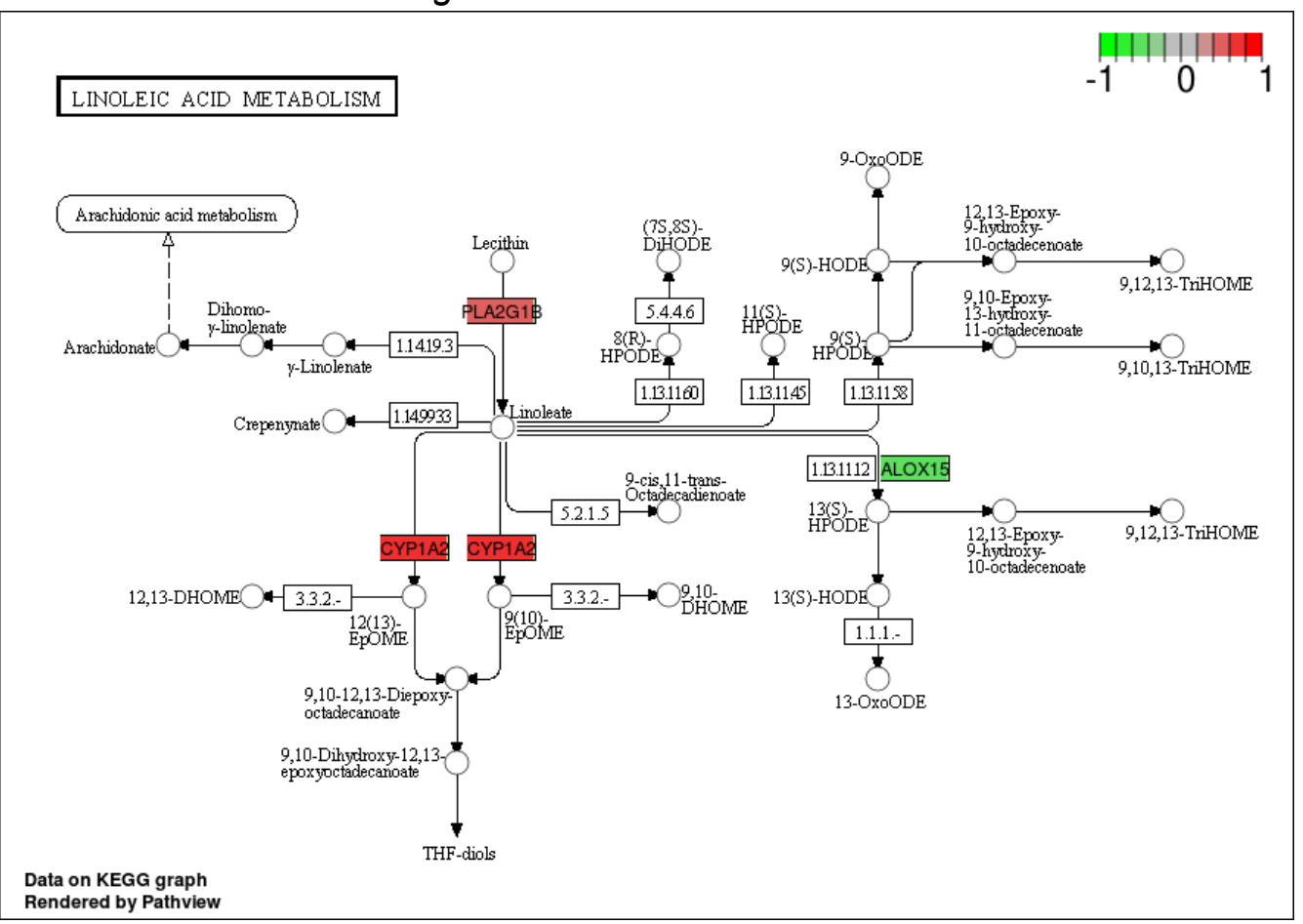

\section{LINOLEIC ACID METABOLISM}

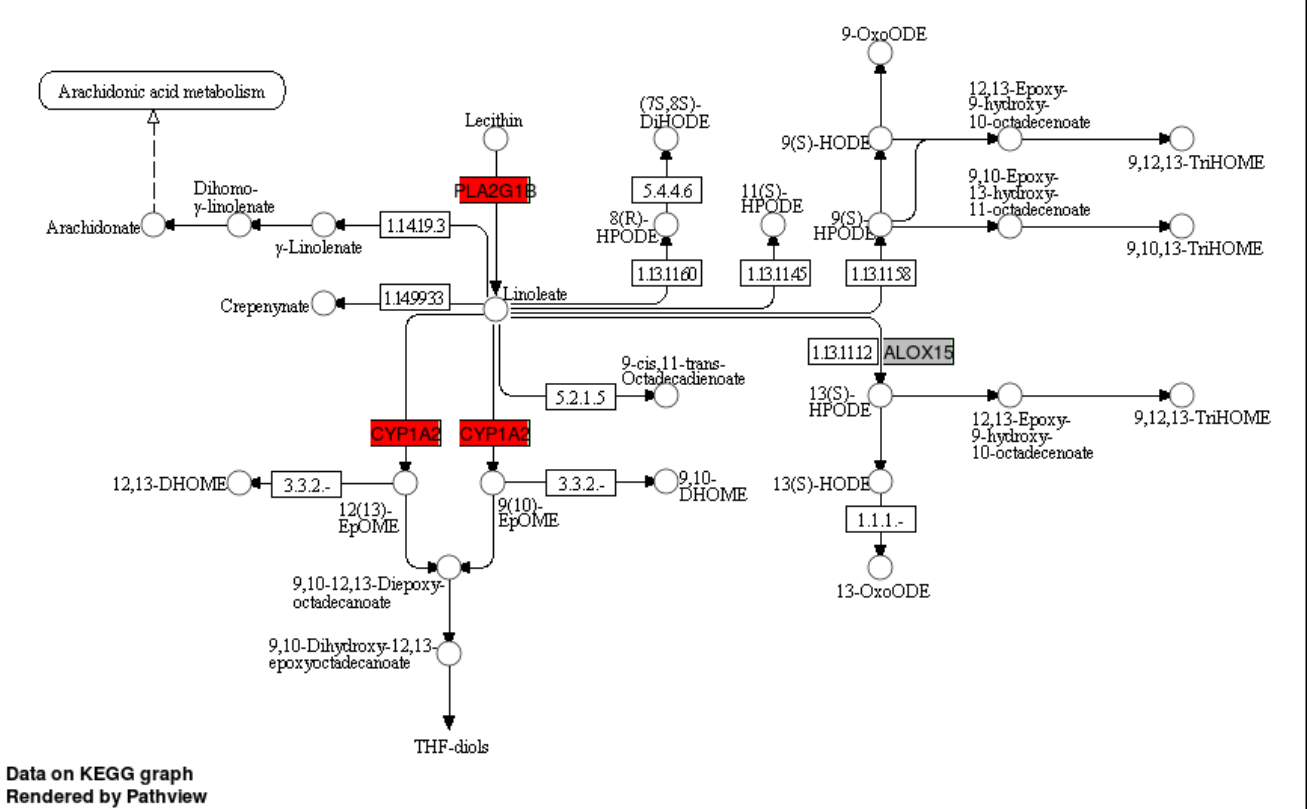

Data on KEGG graph
Rendered by Pathview

\section{LPS}

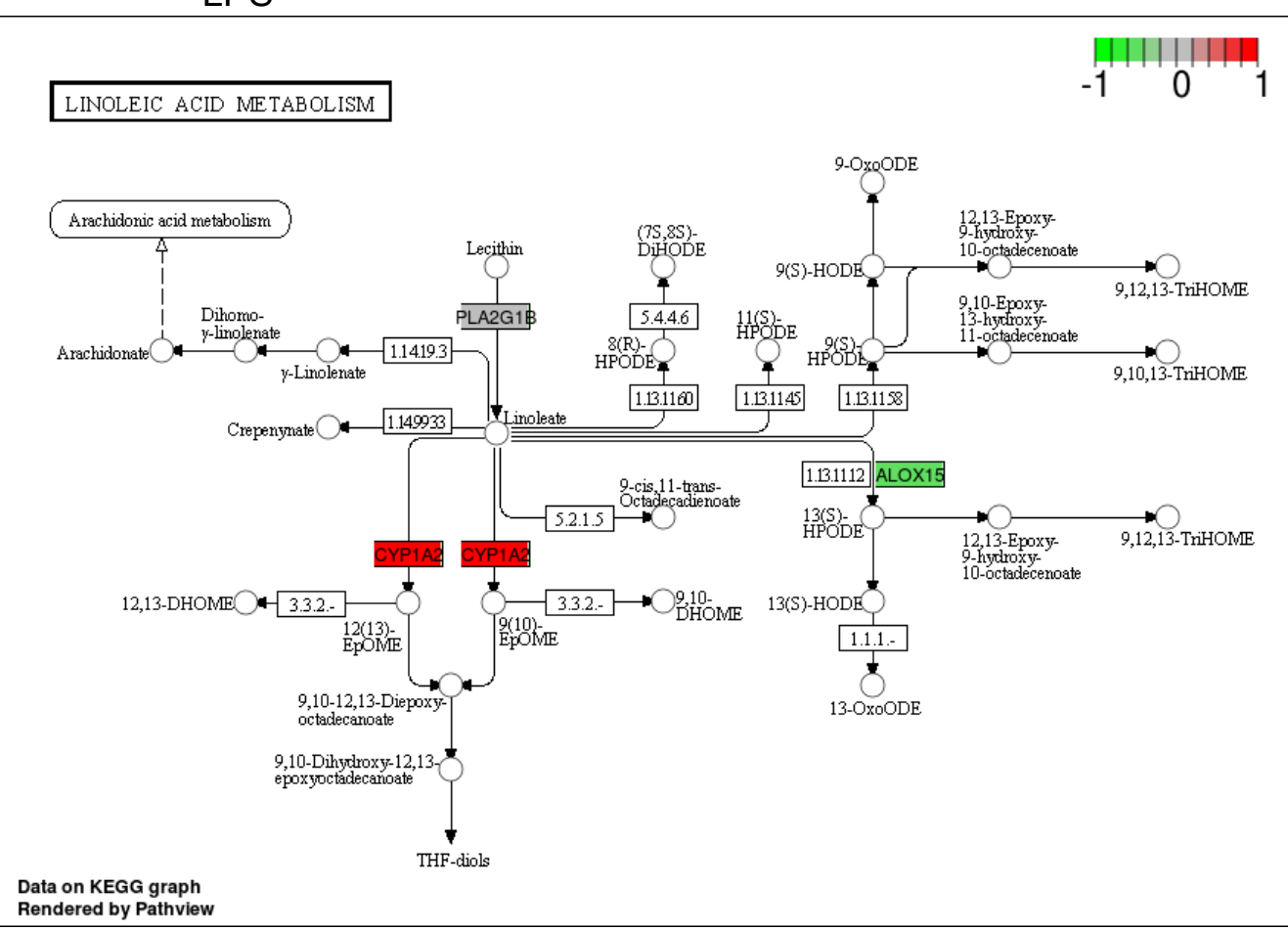




\section{Coxiella burnetii}

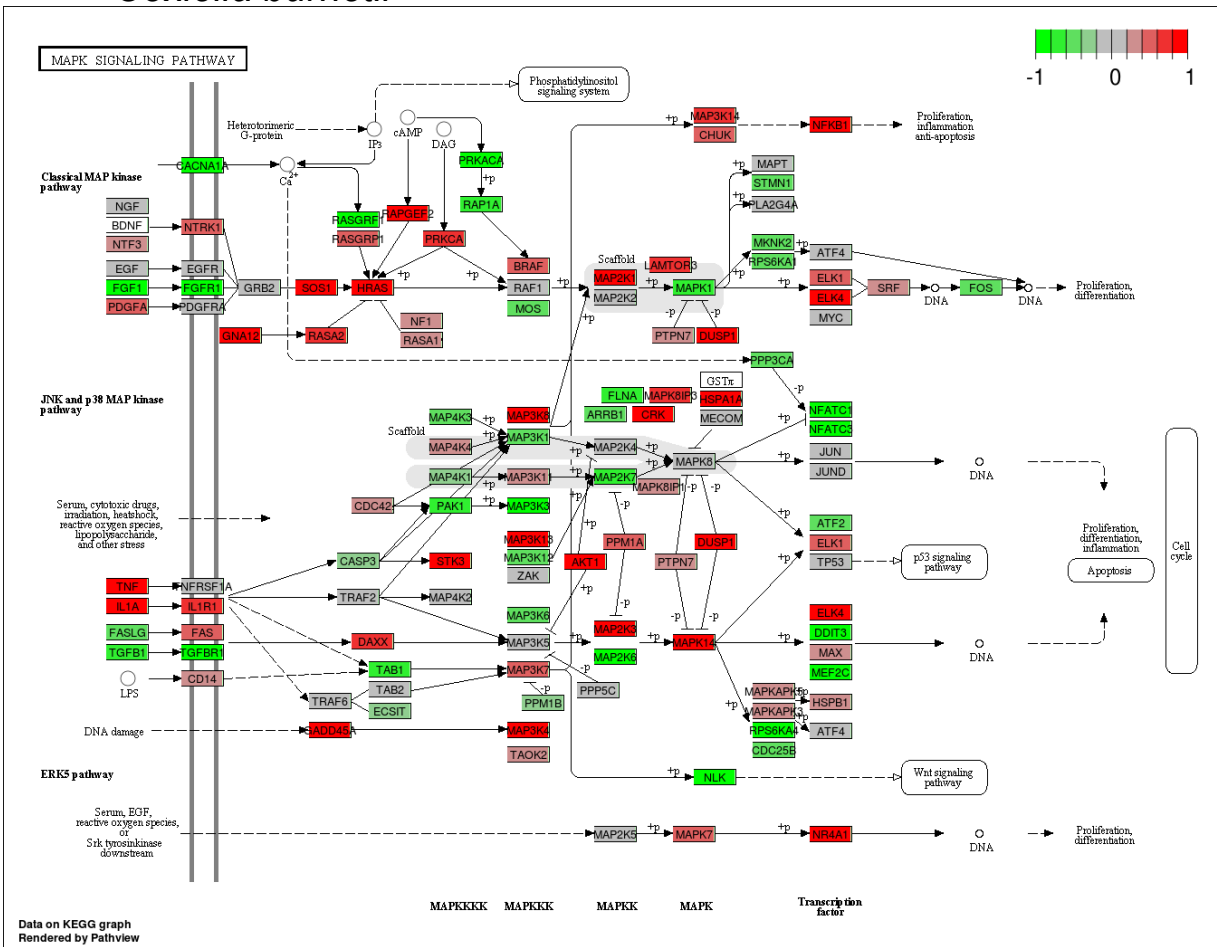

\section{Orientia tsutsugamush}

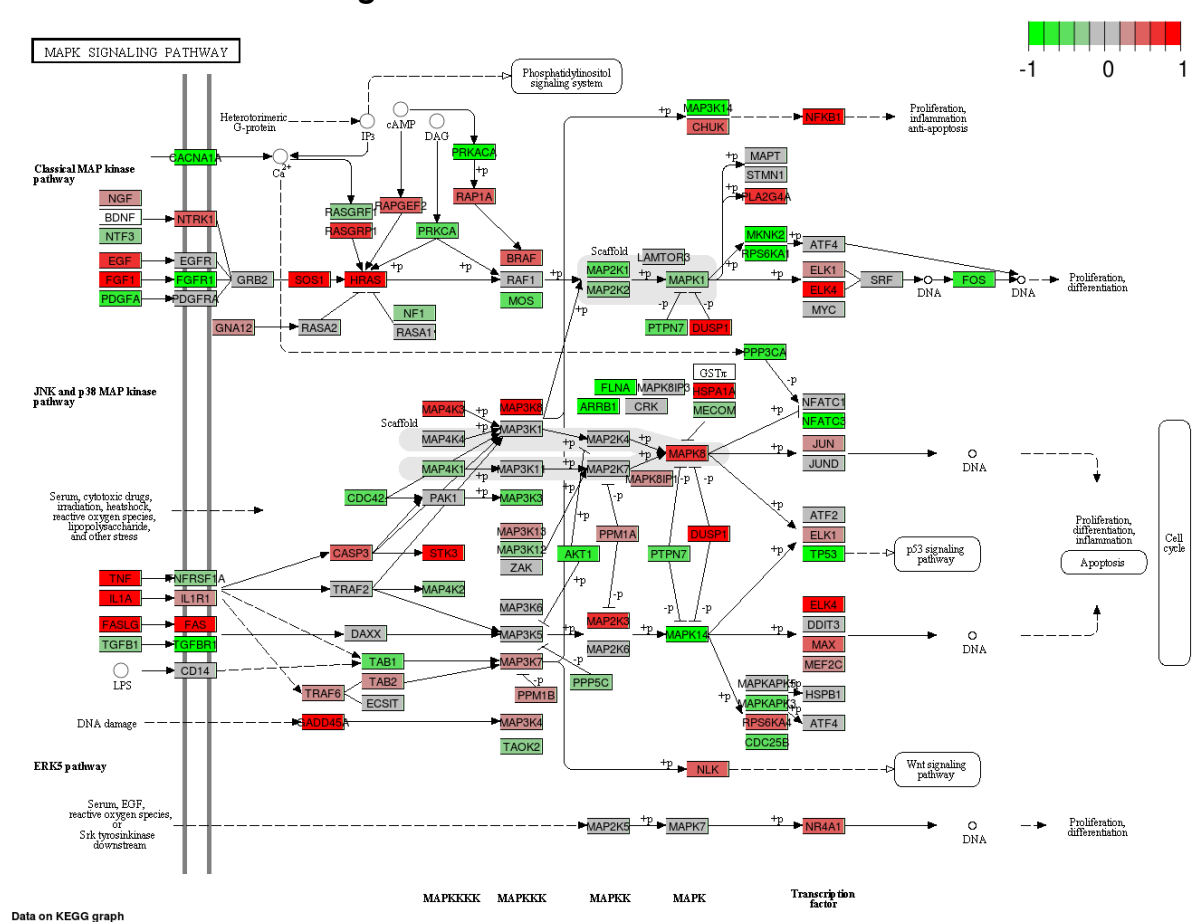

\section{Brucella abortus}

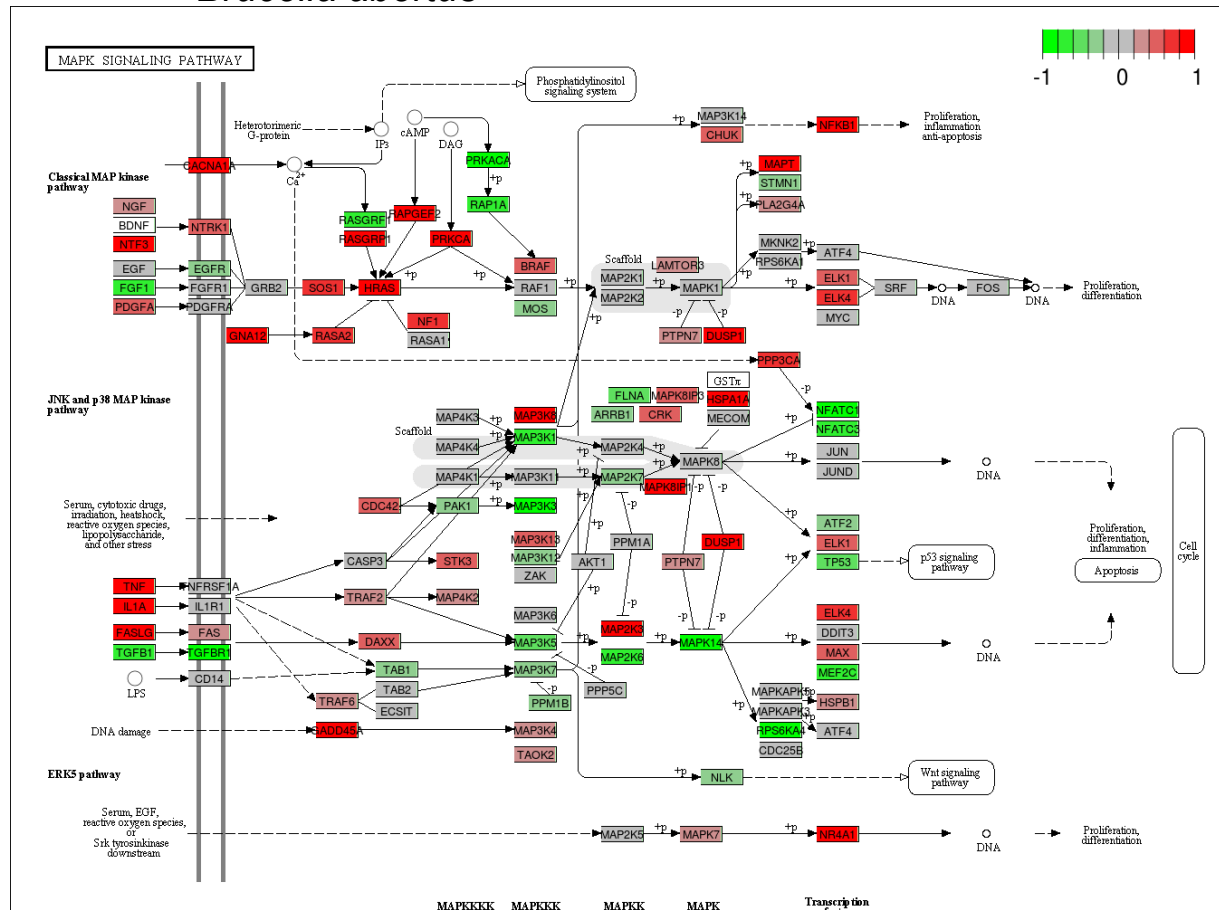

Data on KEGG Graph
Renderod by

MAPKKKK MA MFKK MAPRK MAPK

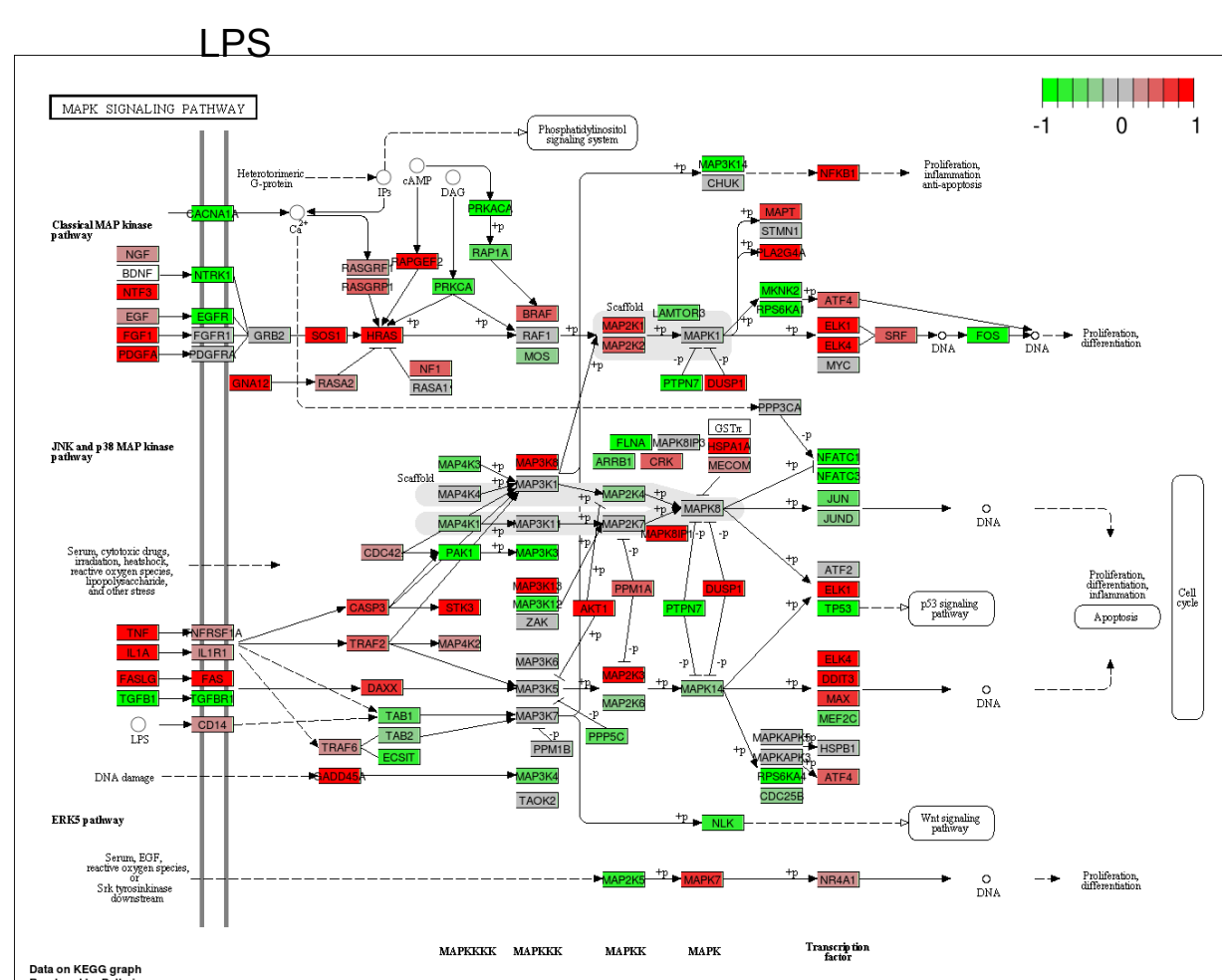




\section{Coxiella burnetii}

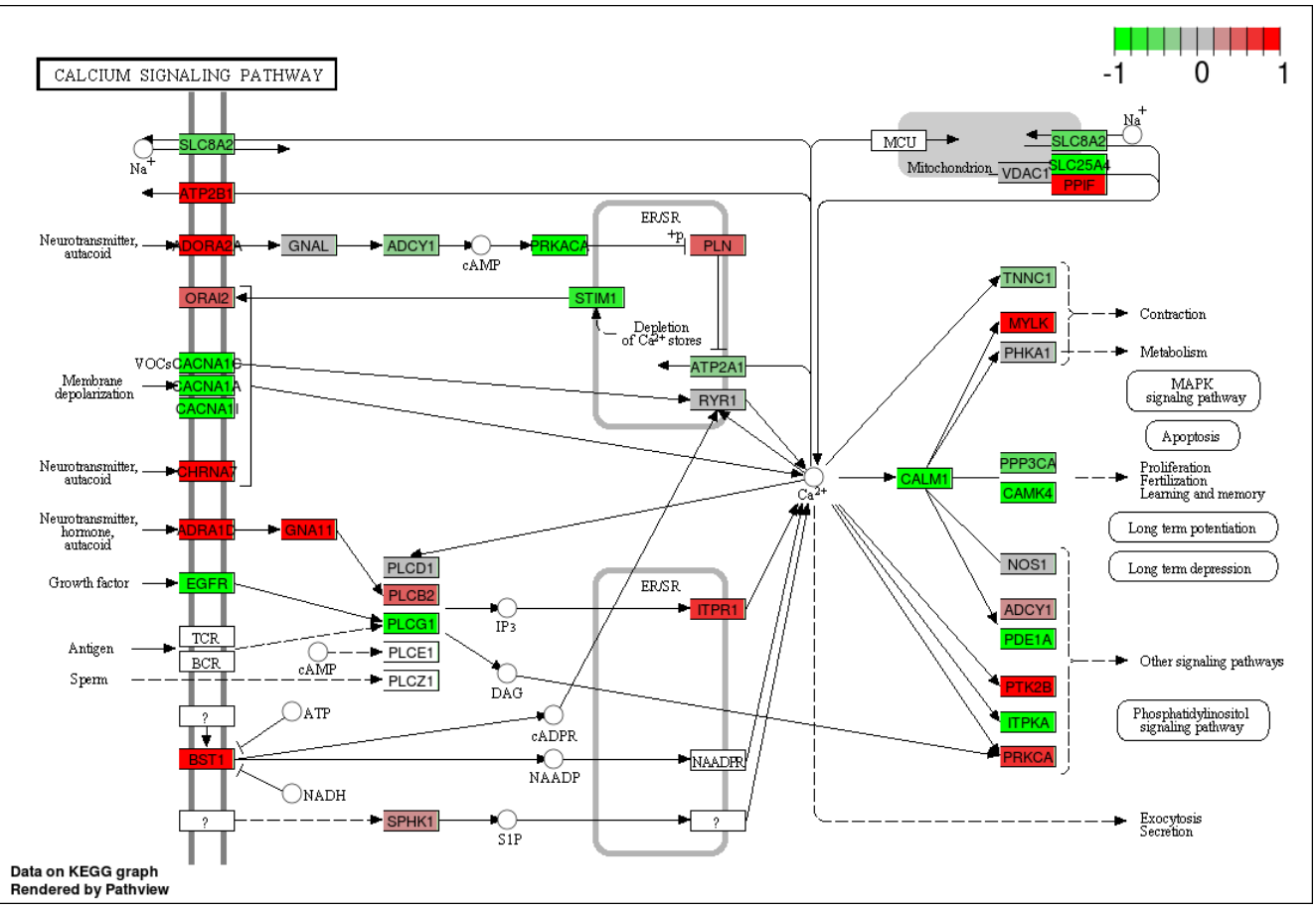

\section{Orientia tsutsugamushi}

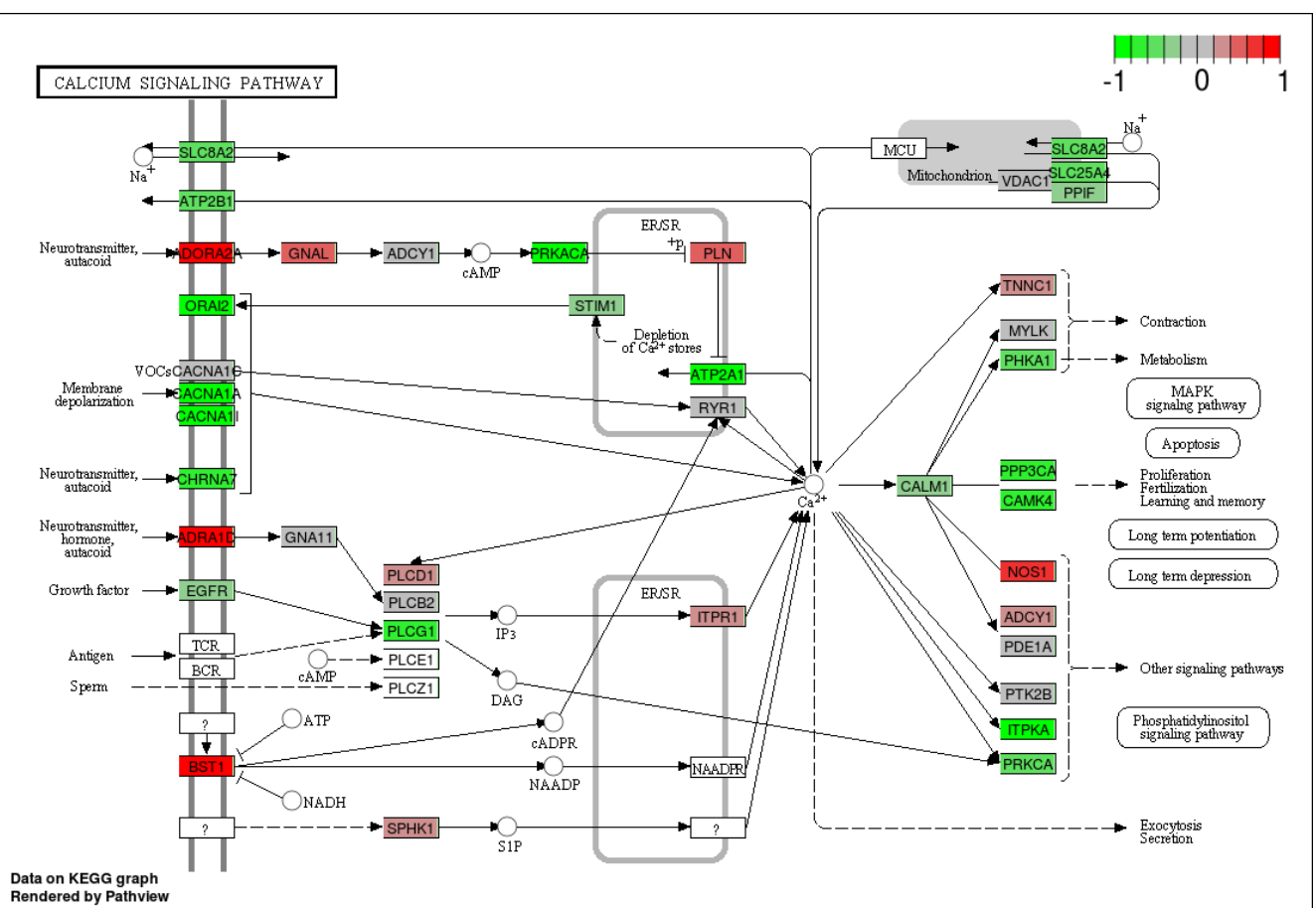

Brucella abortus

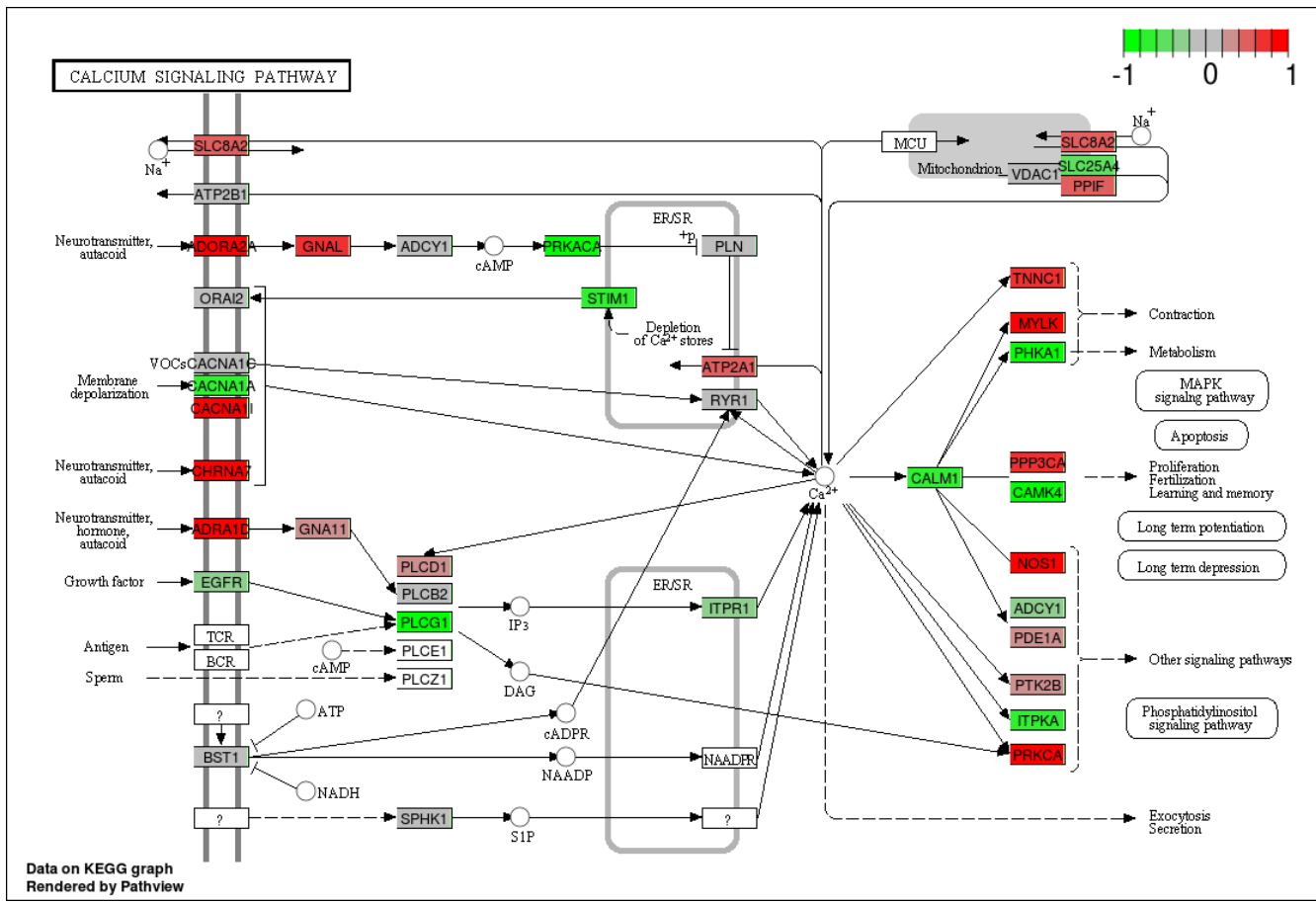

\section{LPS}

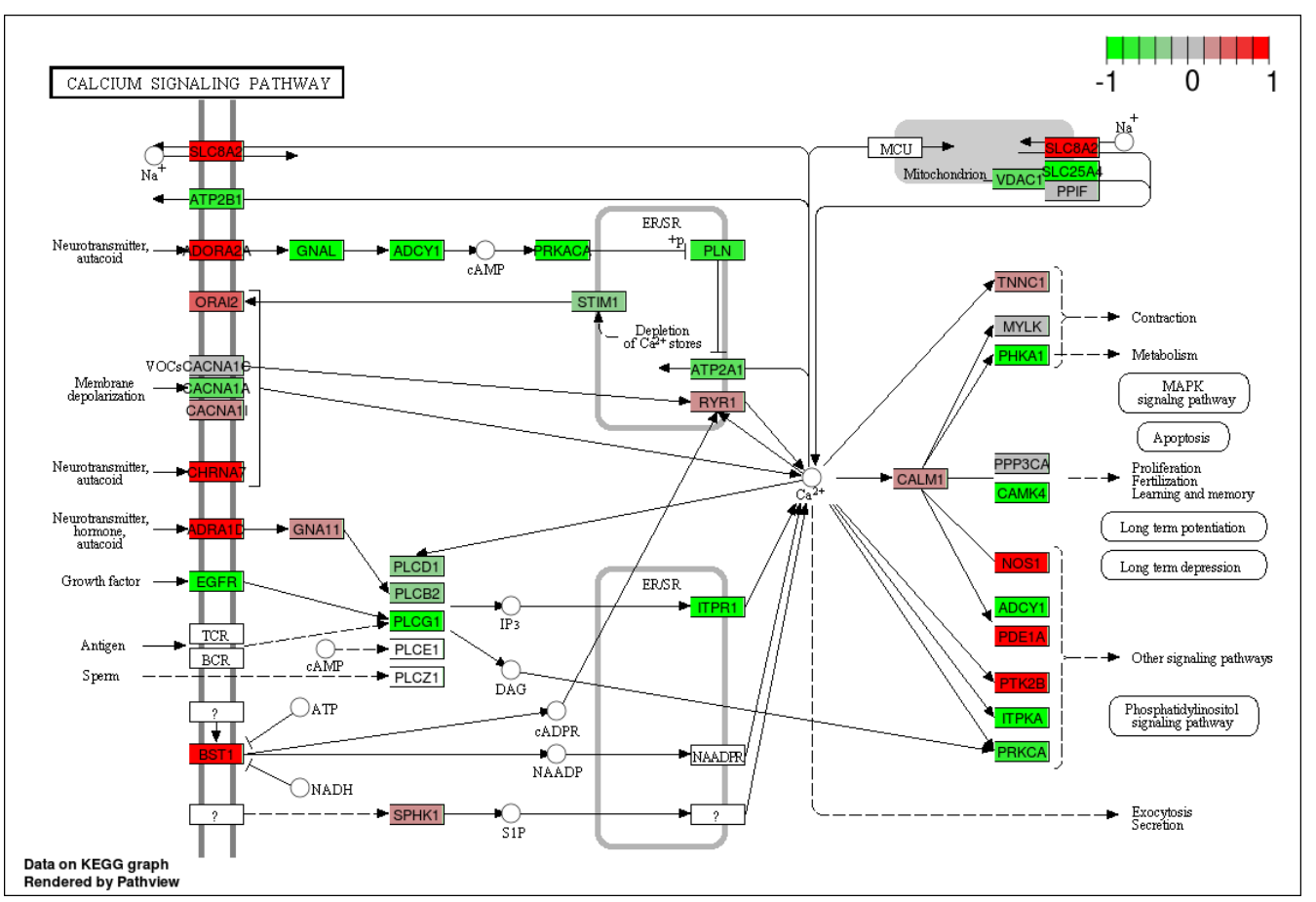


Coxiella burnetii

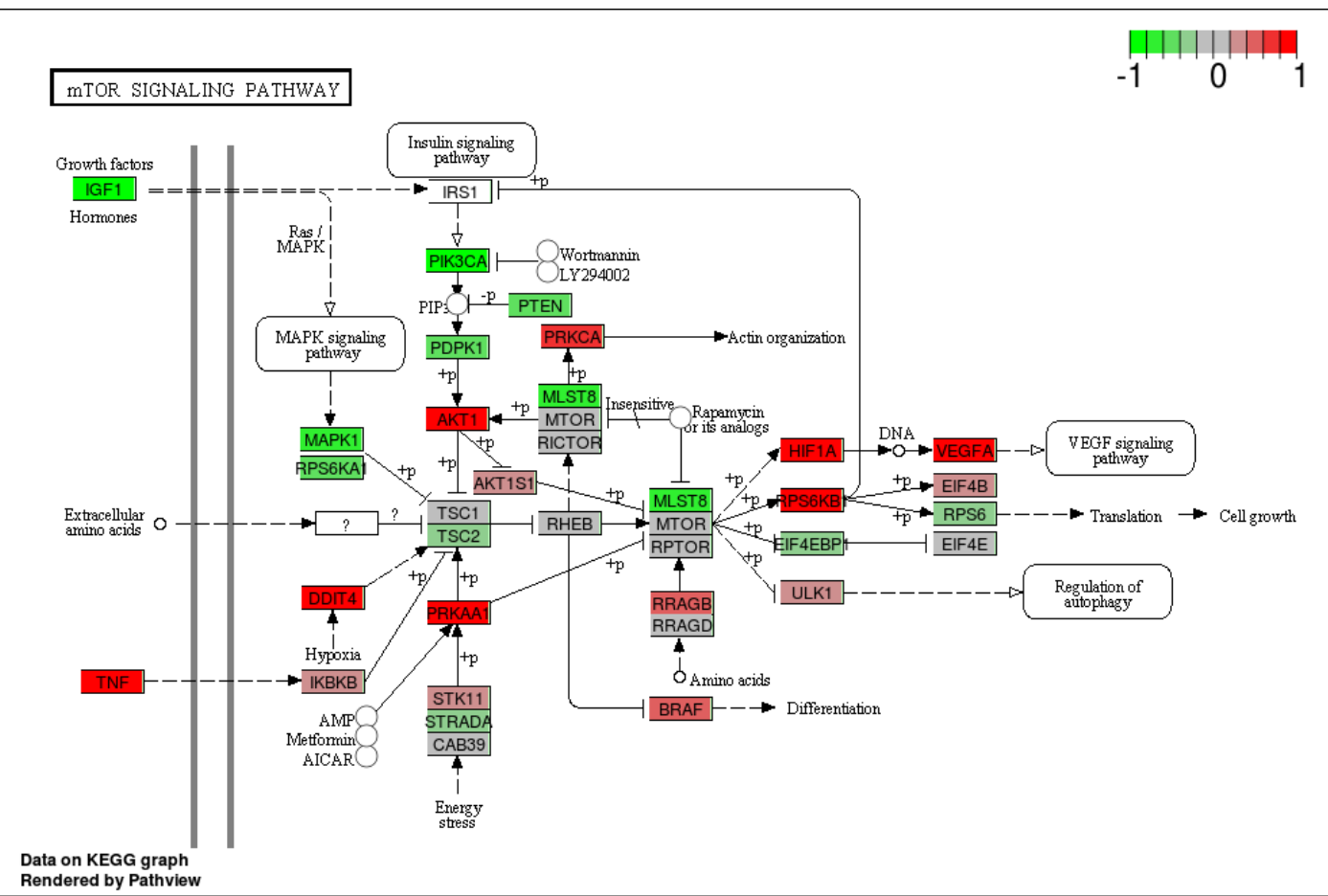

Data on KEGG graph
Rendered by pathview

\section{Orientia tsutsugamushi}

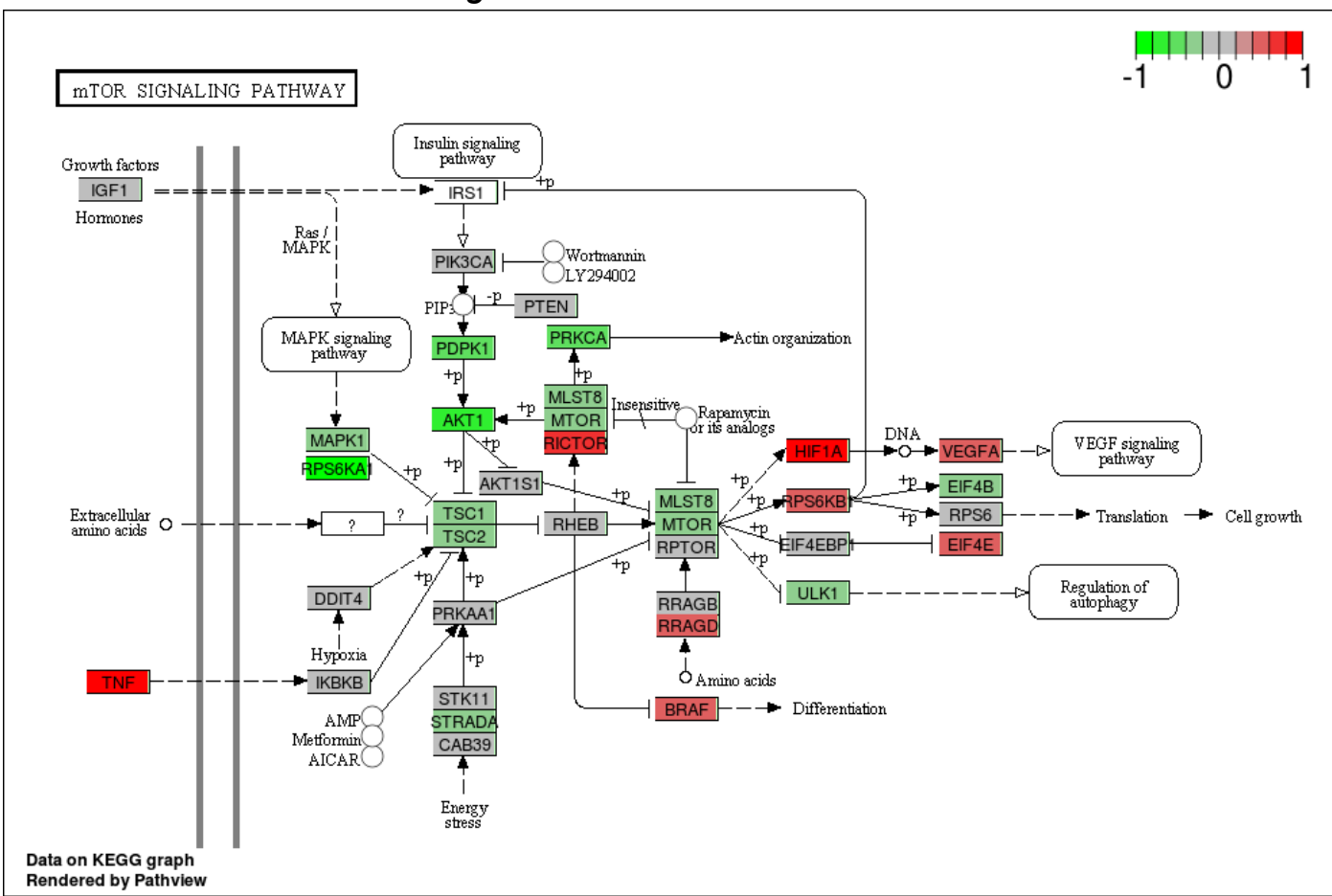

Brucella abortus

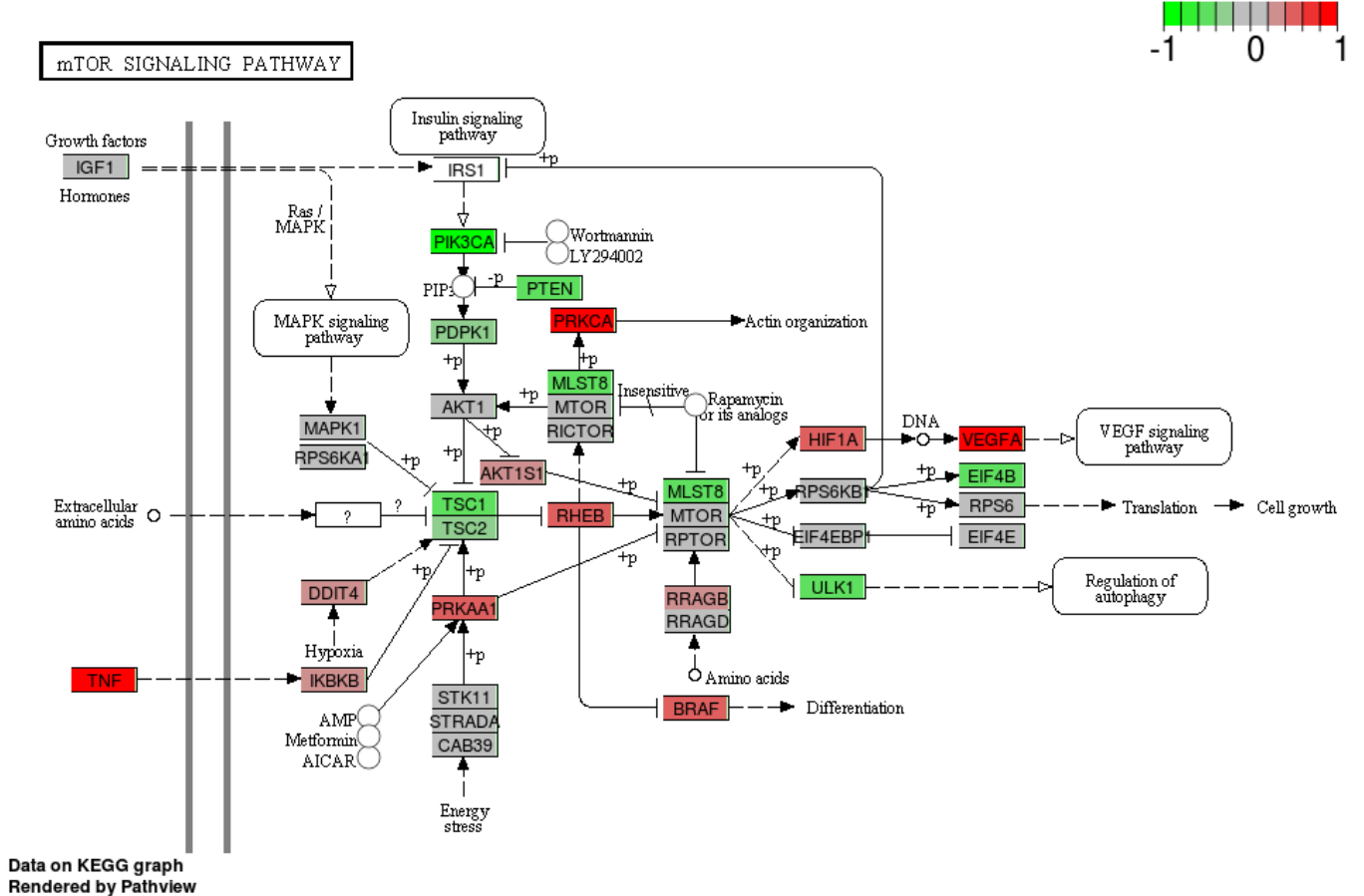

Data on KEGG graph
Rendered by Pathview

LPS

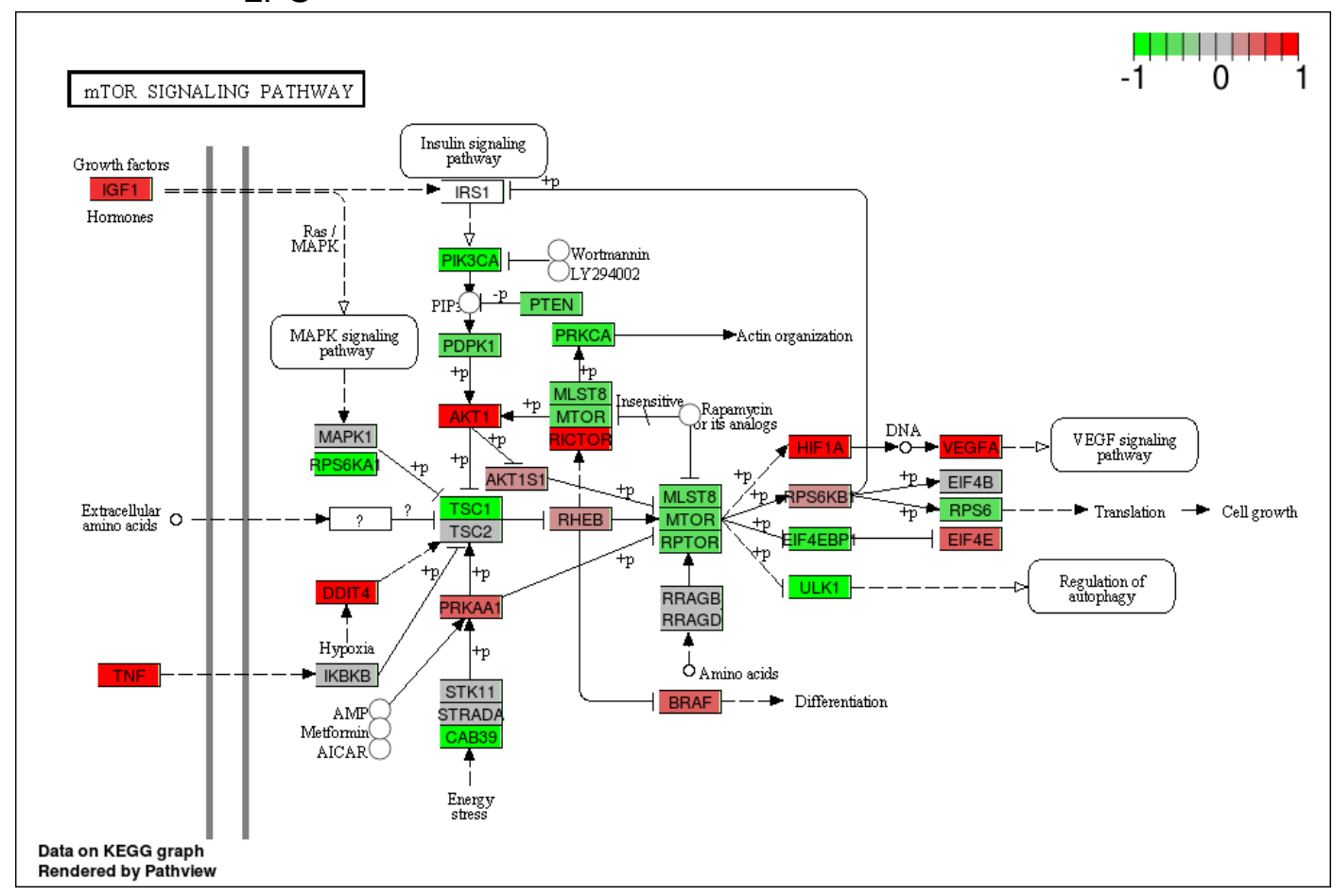




\section{Coxiella burnetii}

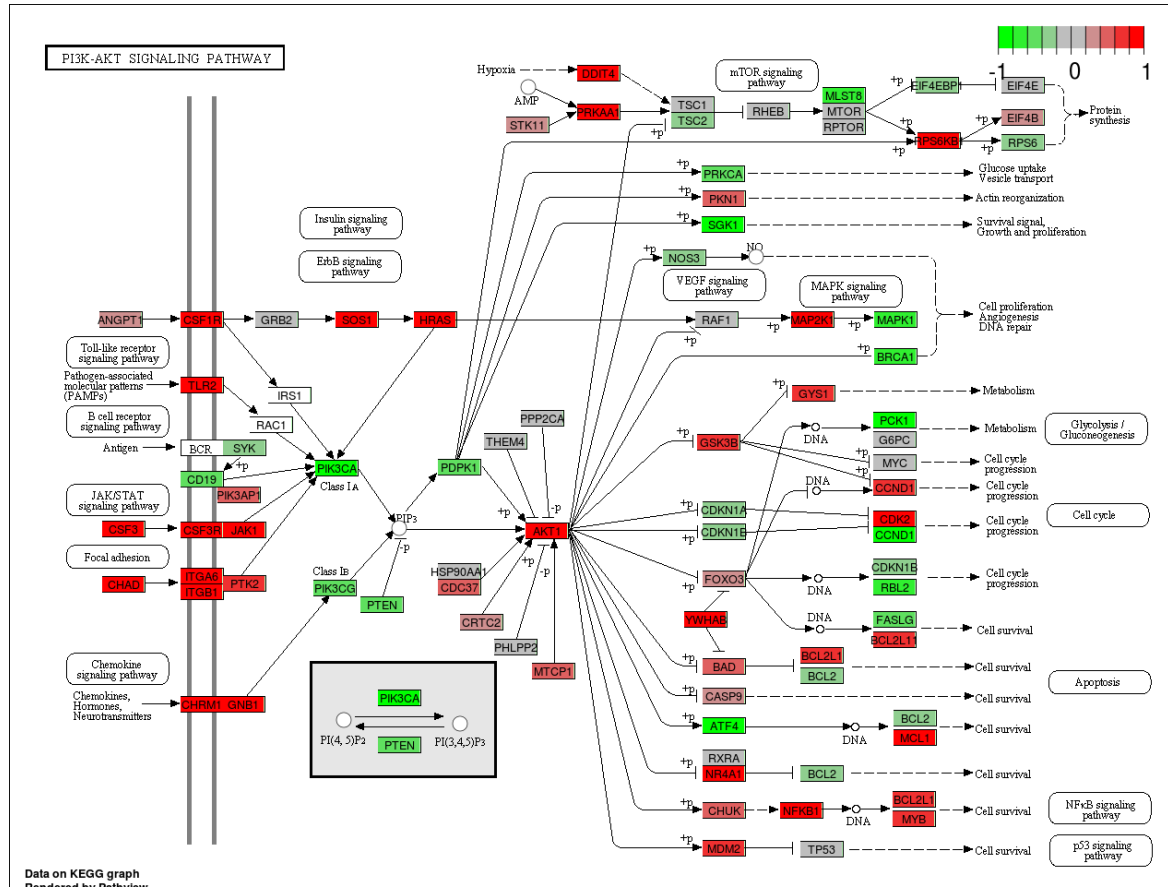

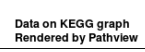

\section{Orientia tsutsugamushi}

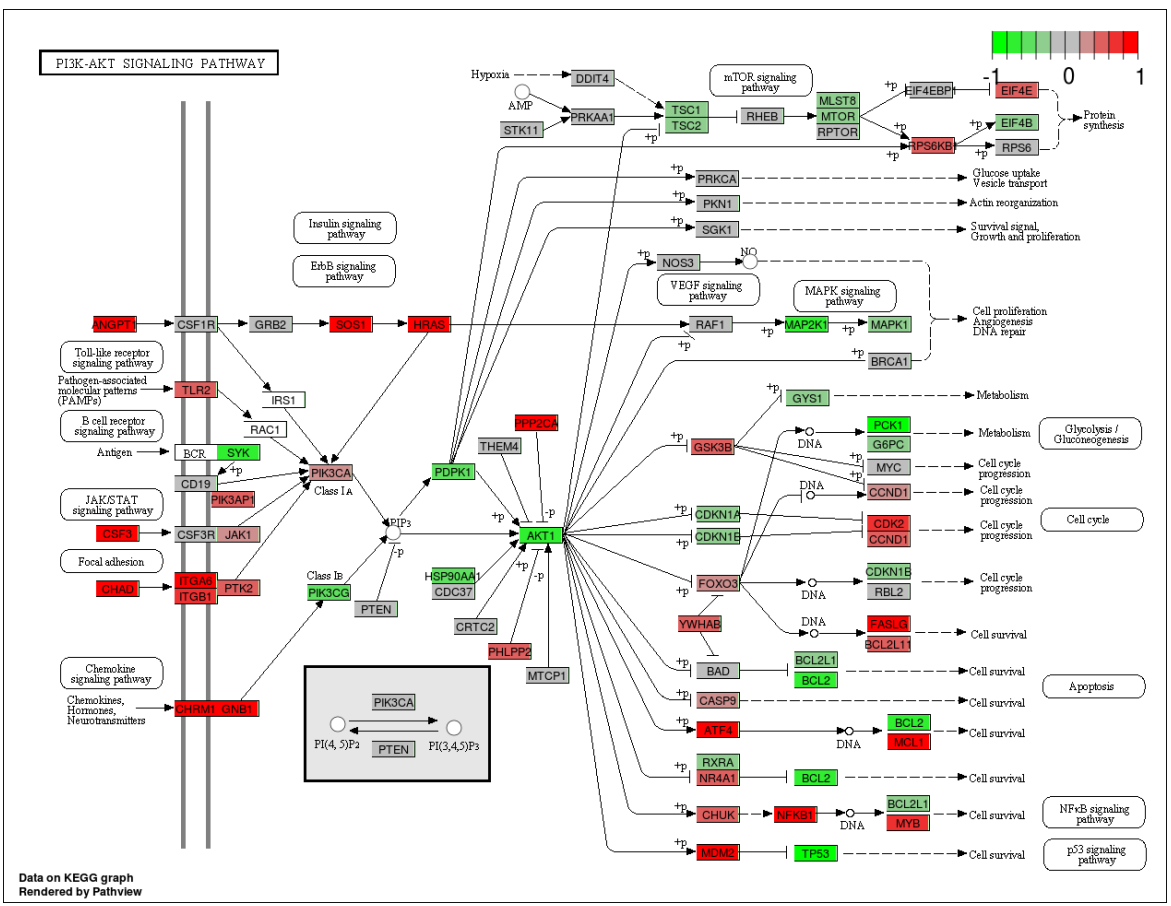

\section{Brucella abortus}

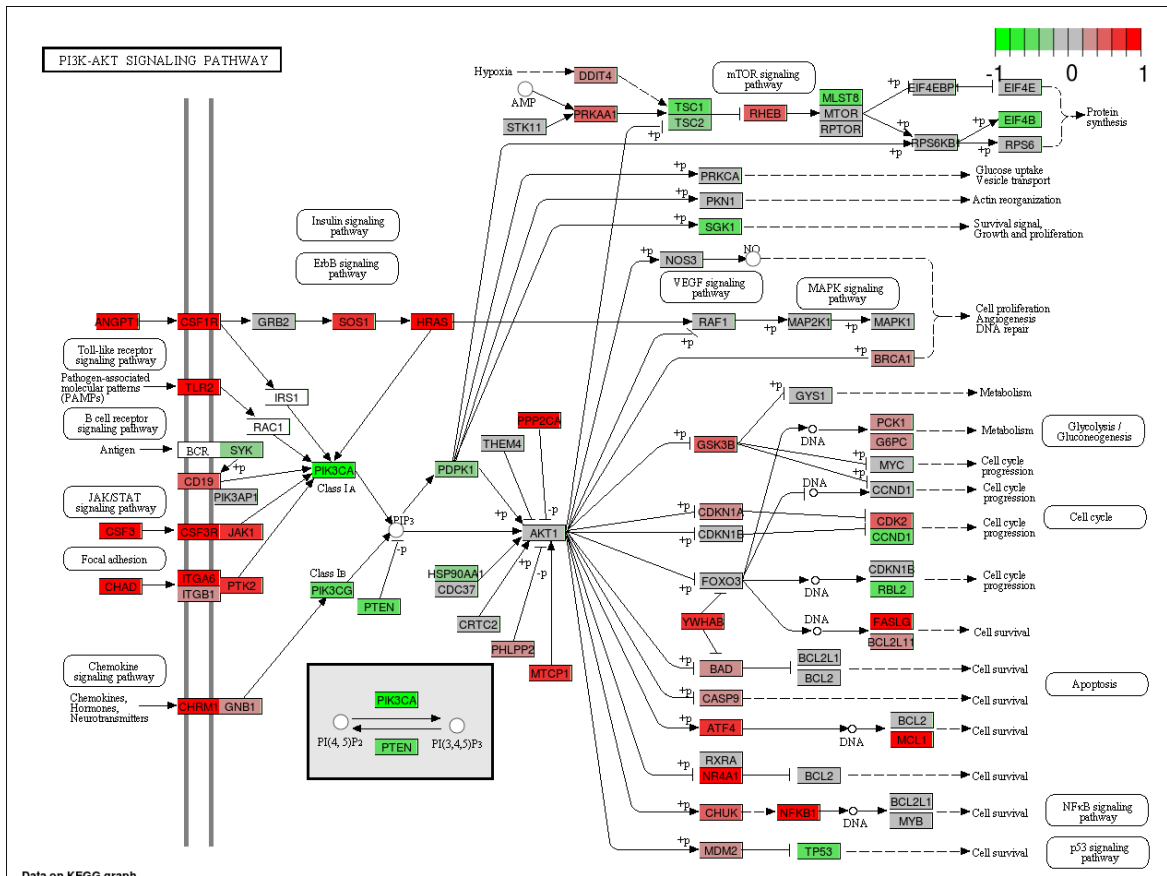

Datan on KEGG graph
Rendered by pathrew

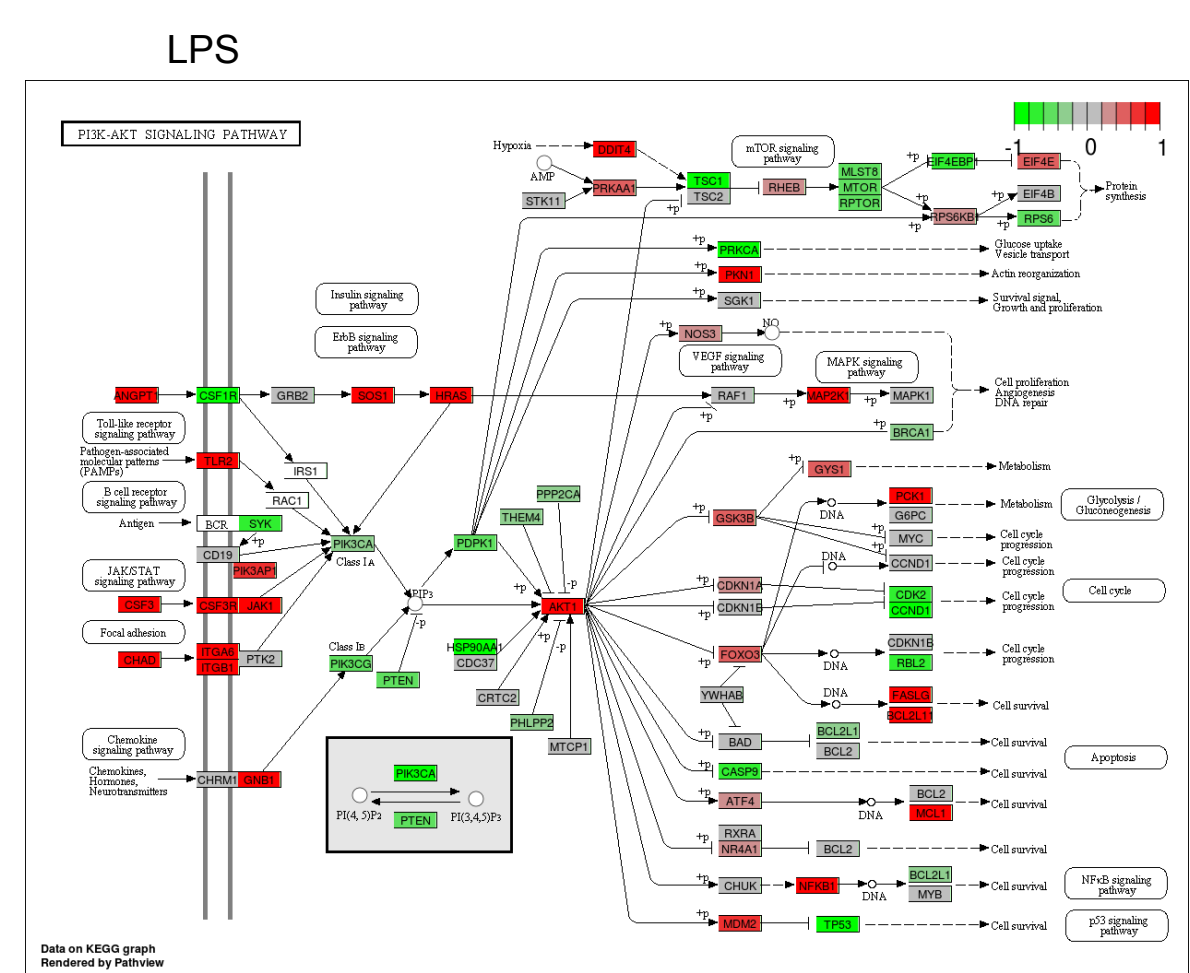




\section{Coxiella burneti}

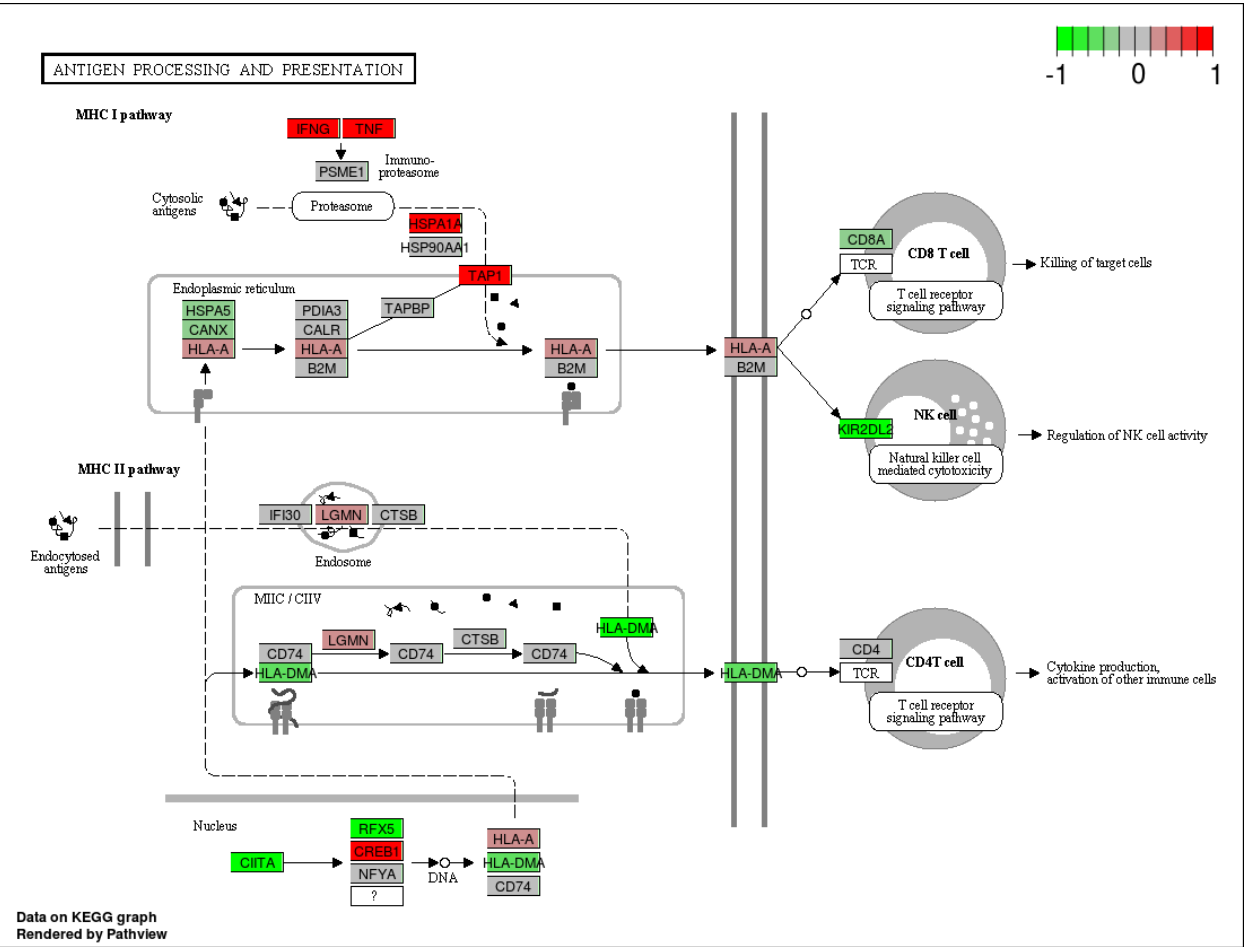

\section{Orientia tsutsugamushi}

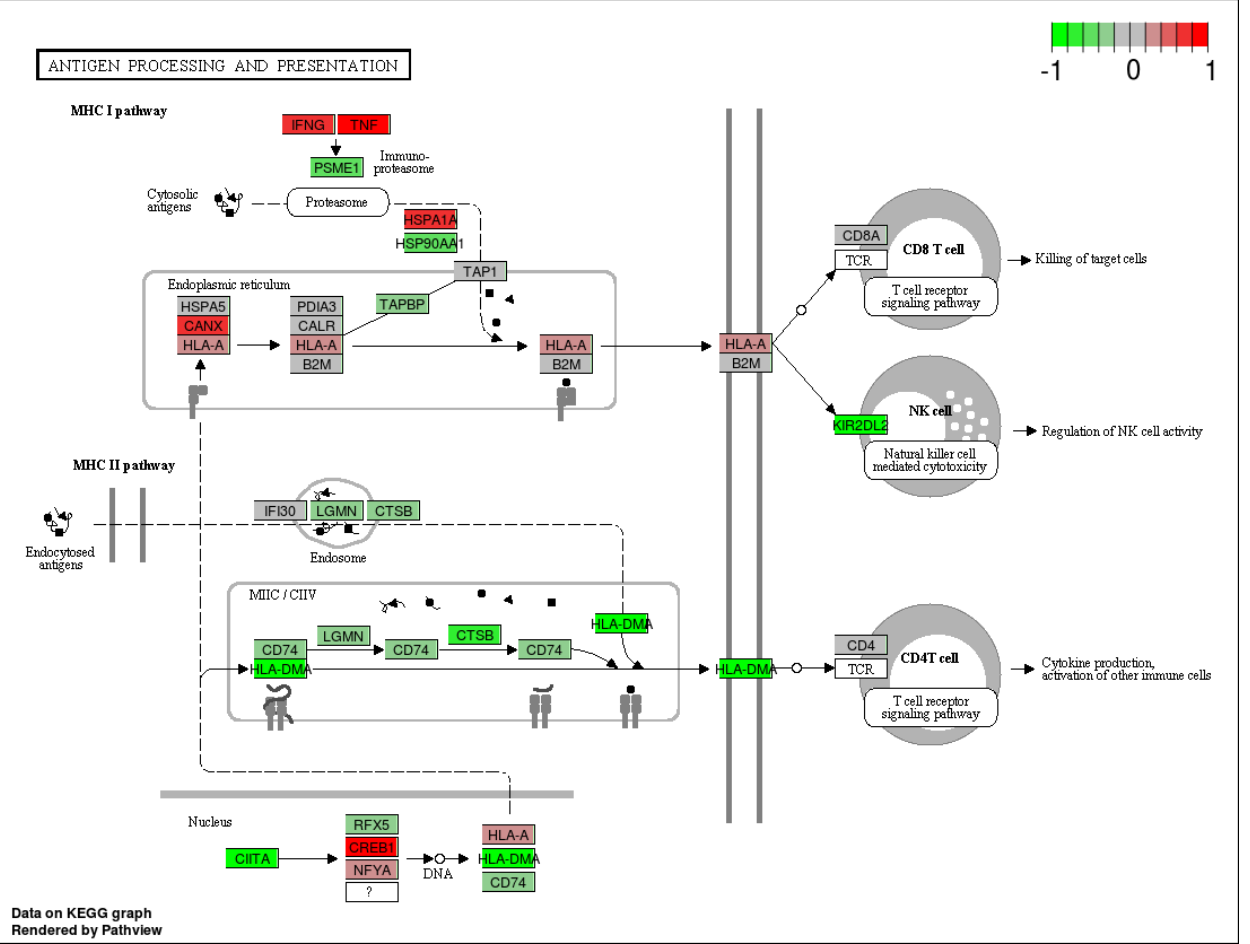

Brucella abortus

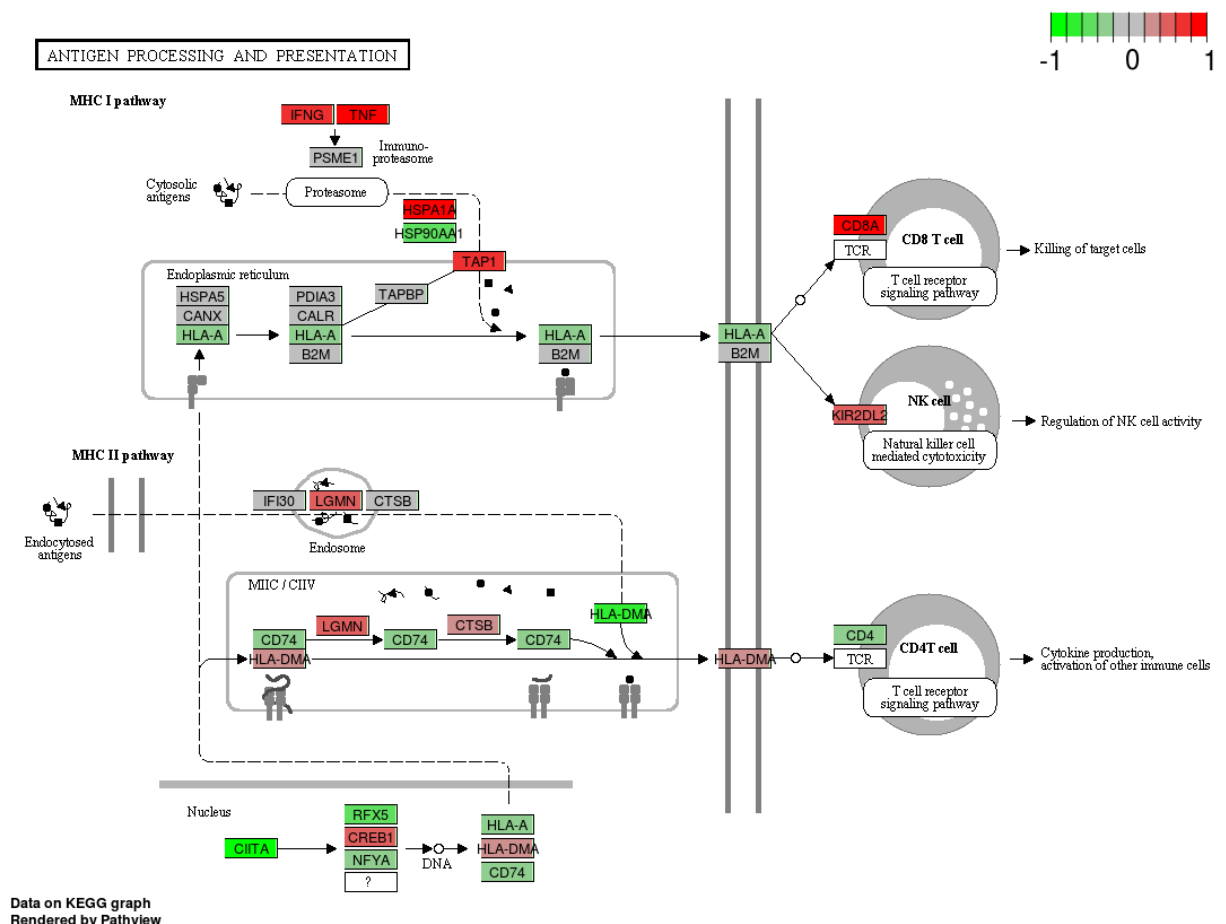

Data on KEGG graph
Rendered by Pathvie

LPS

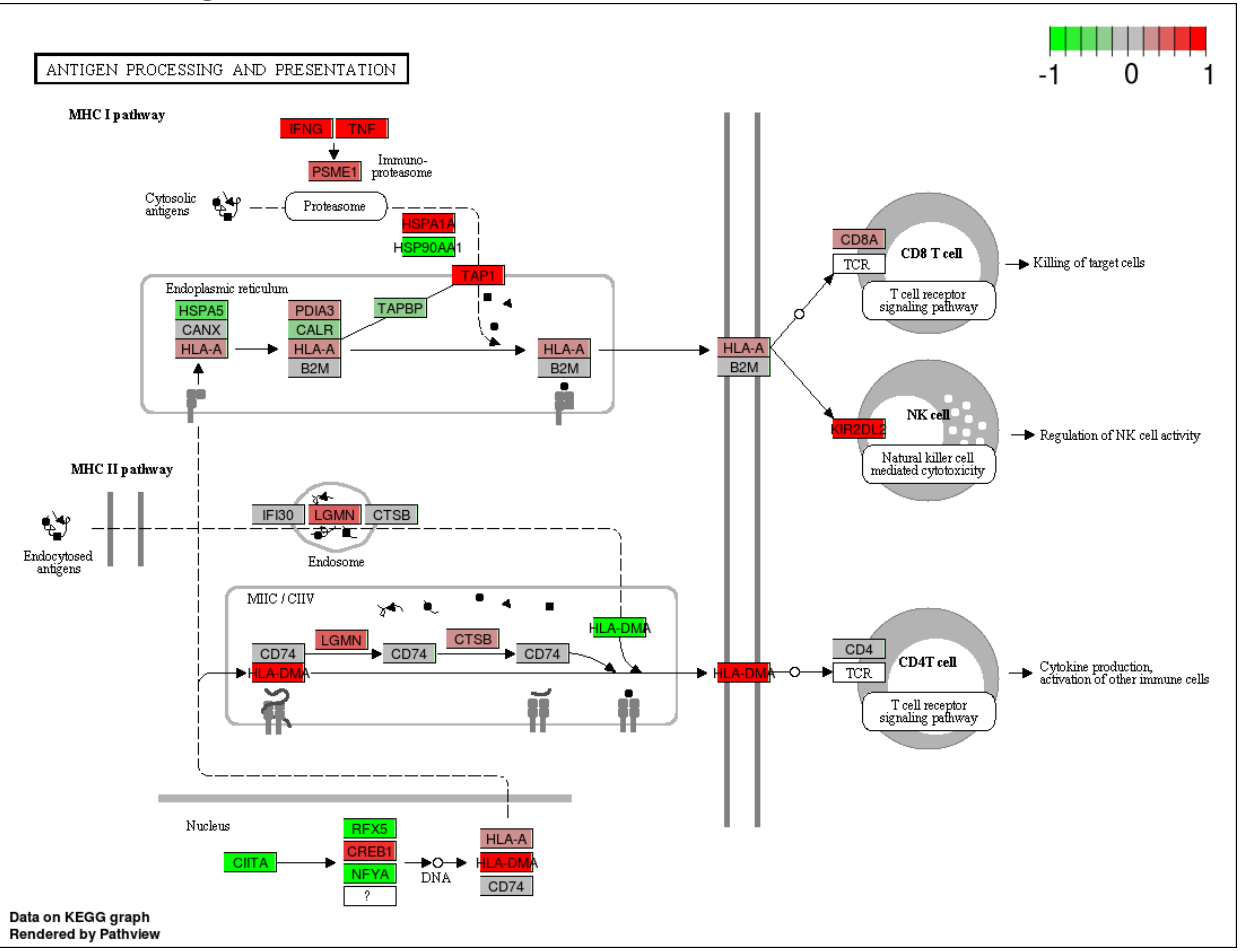




\section{Coxiella burnetii}

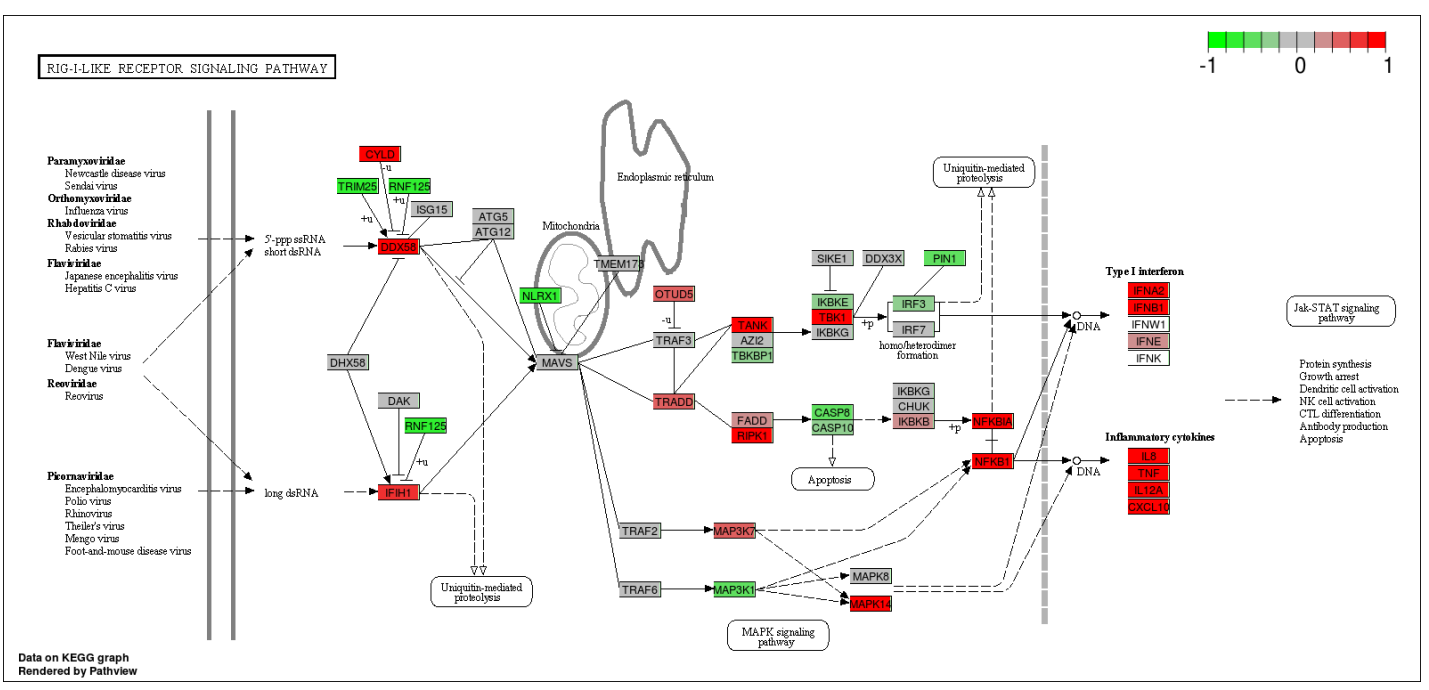

\section{Brucella abortus}

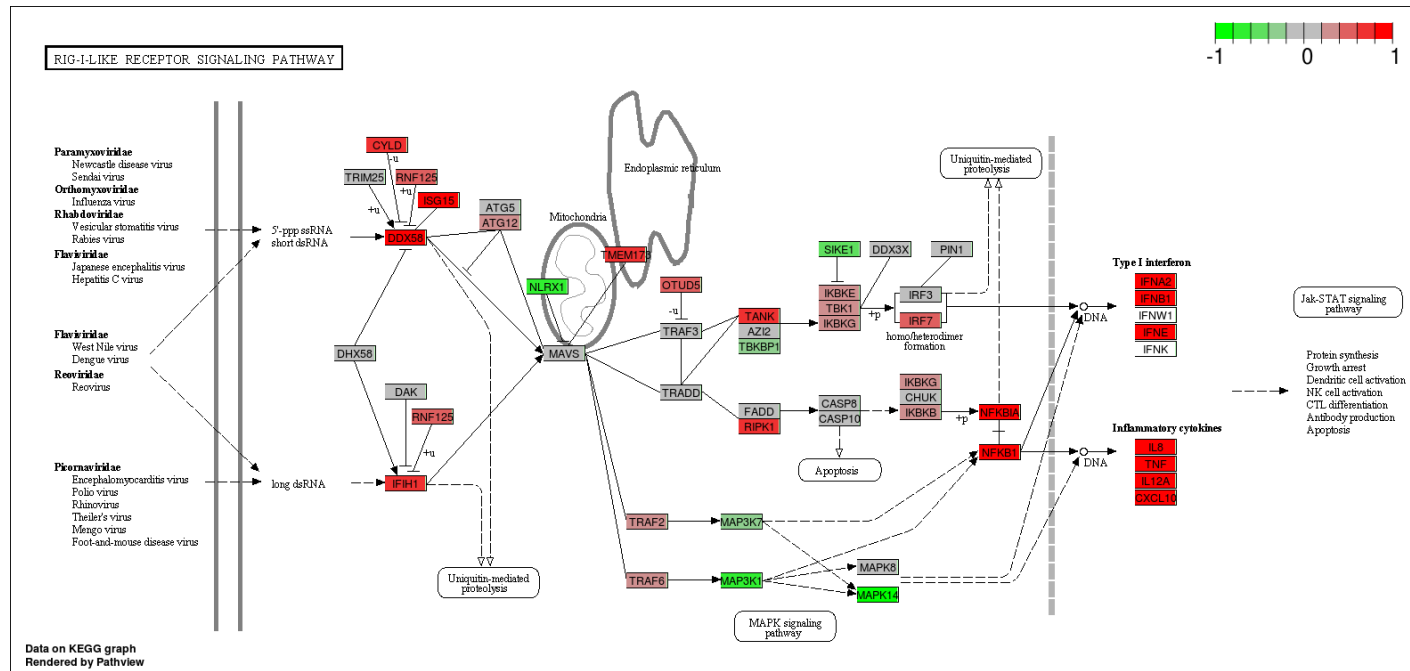

Orientia tsutsugamushi

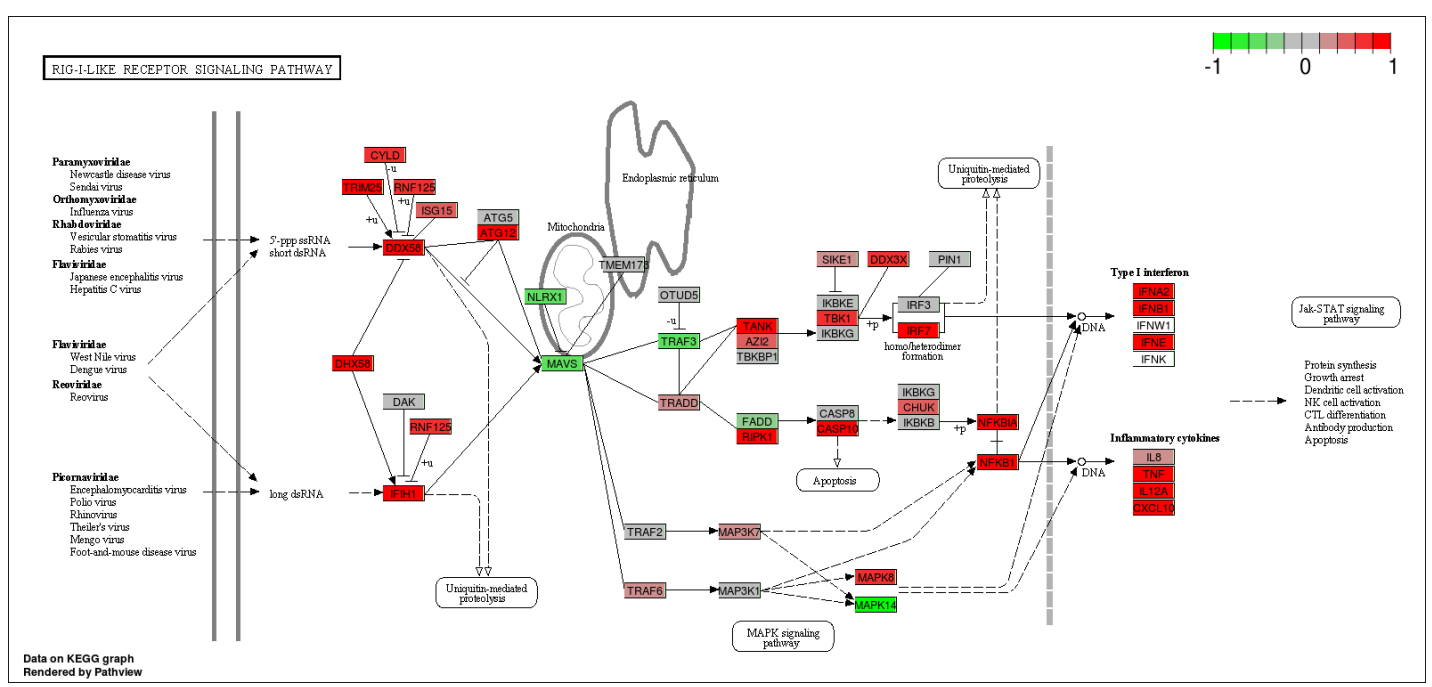

LPS

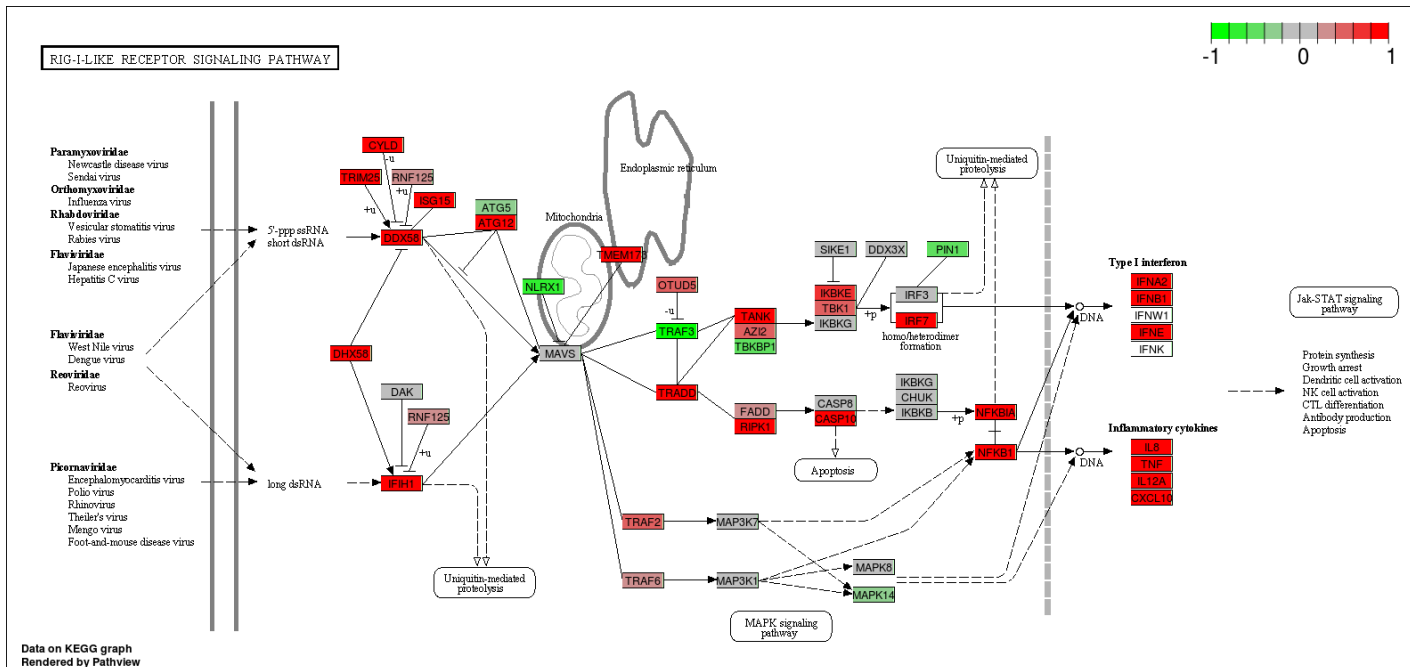




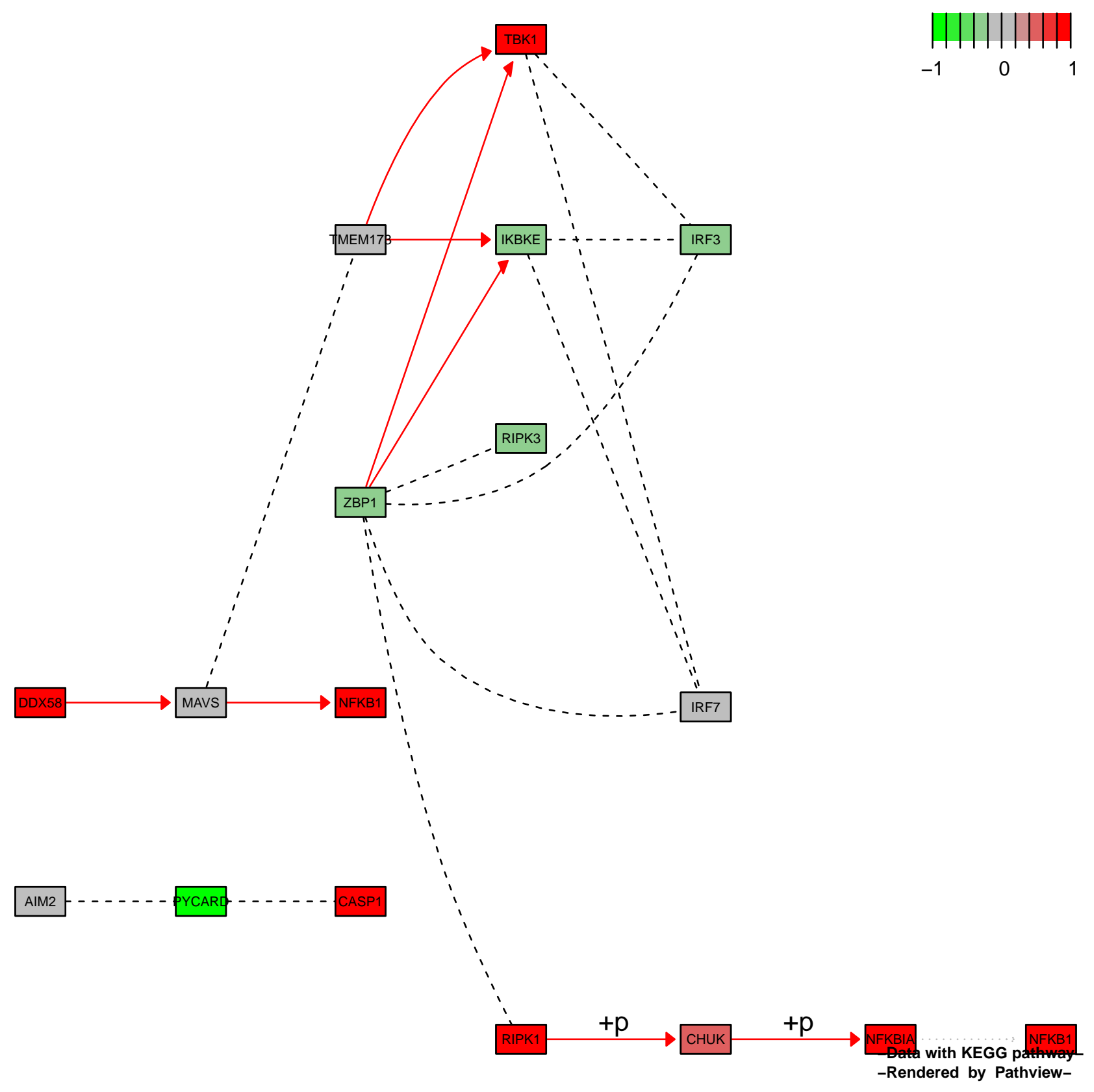

Edge types

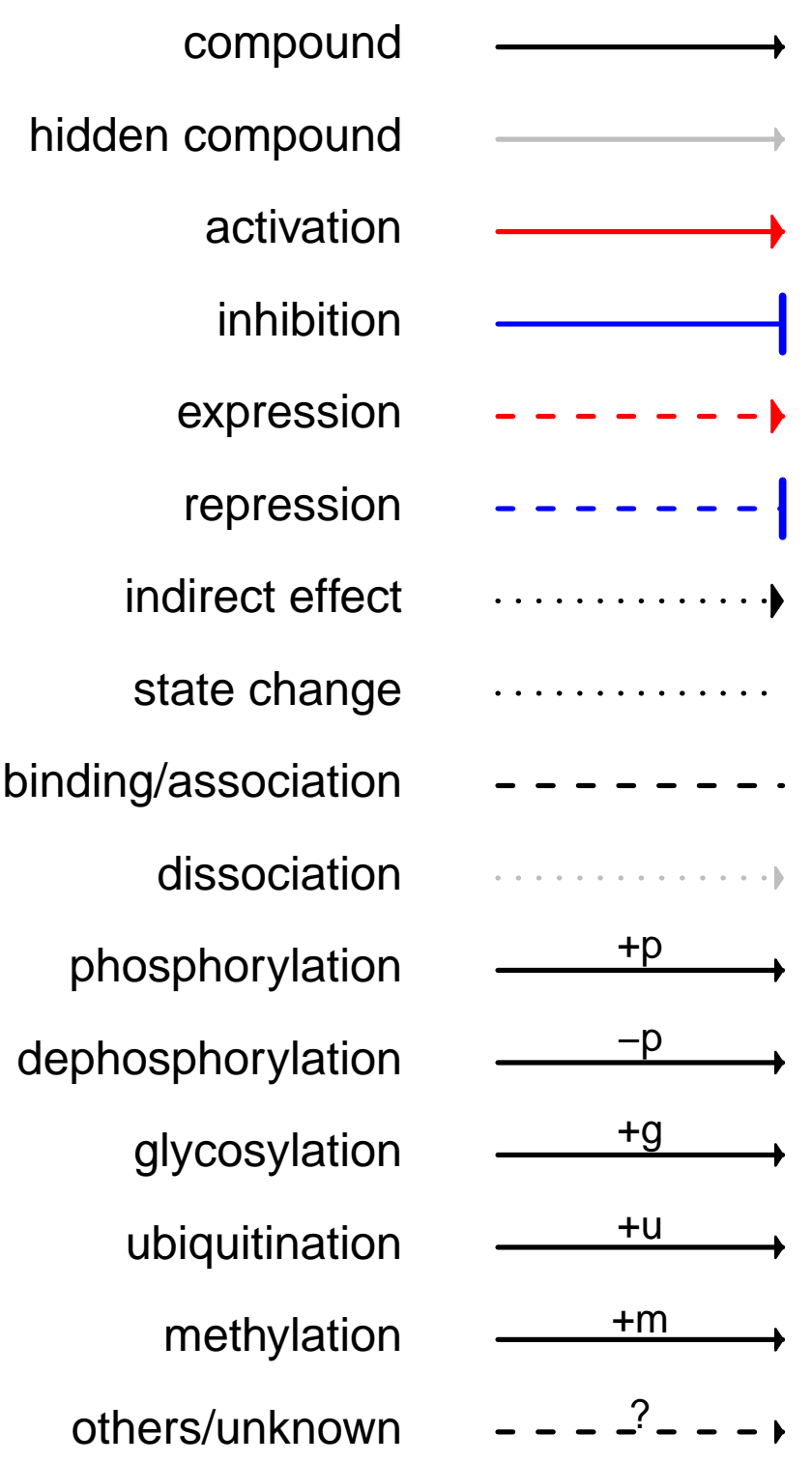




\section{Coxiella burnetii}

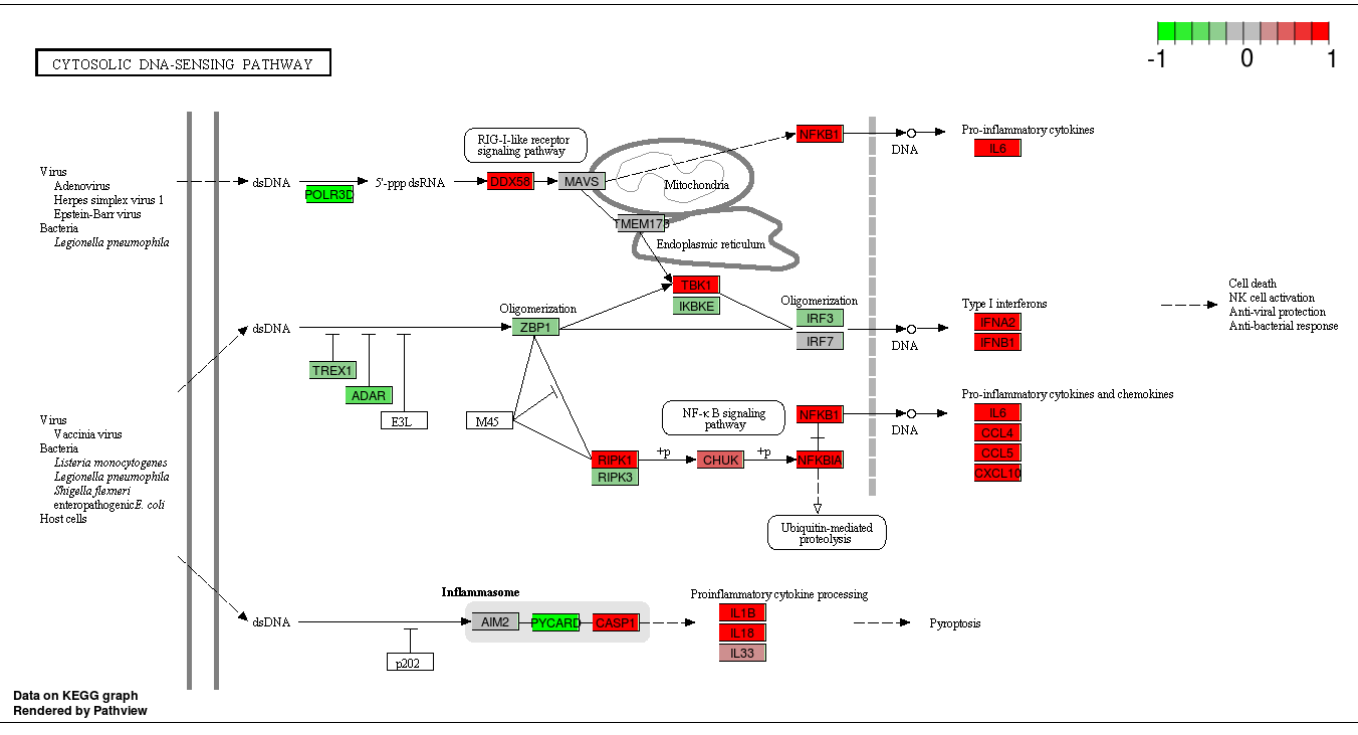

Orientia tsutsugamushi

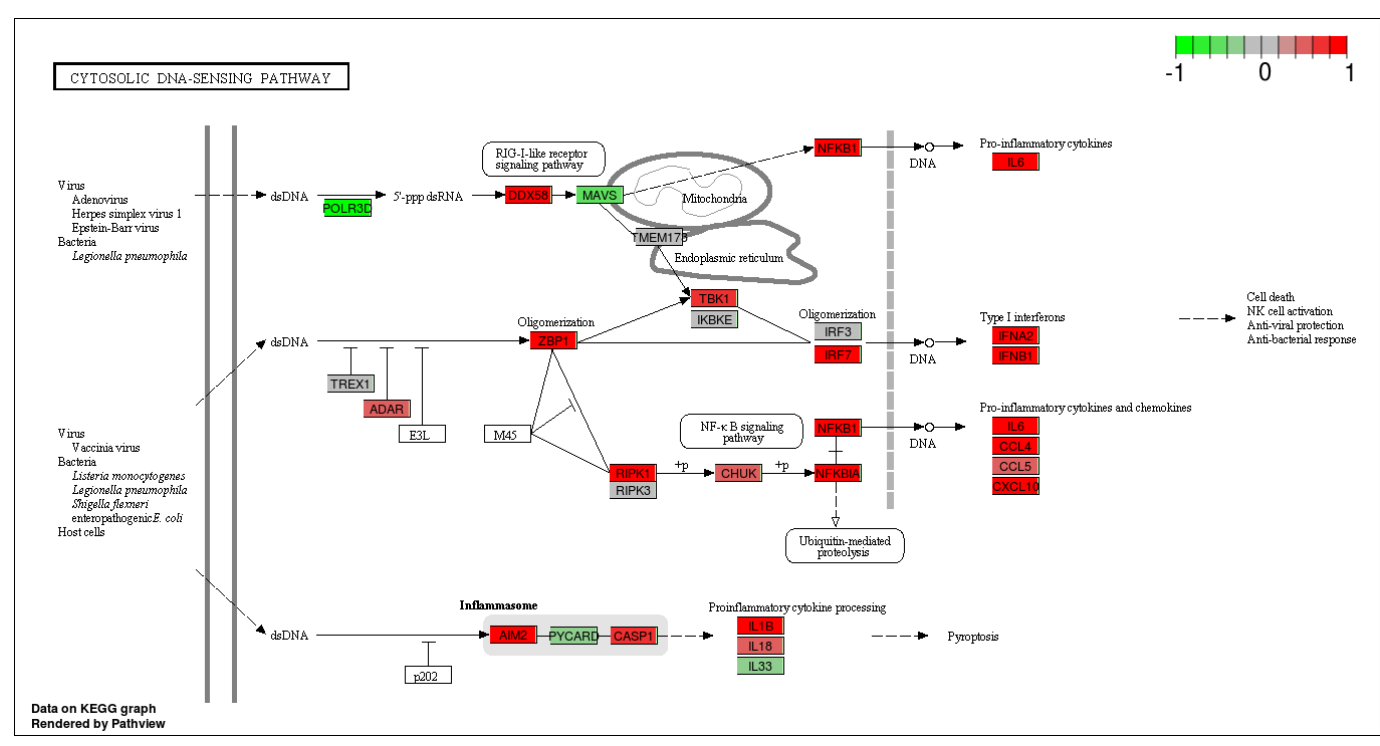

\section{Brucella abortus}

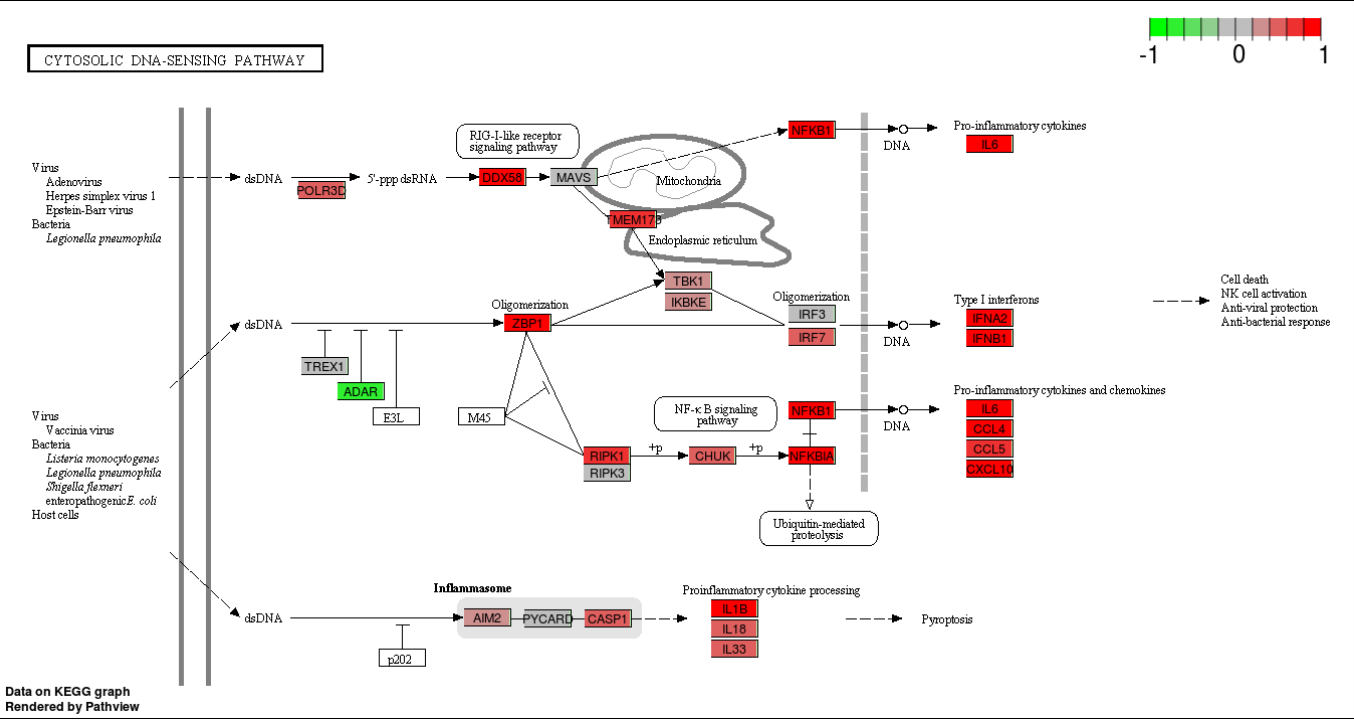

LPS

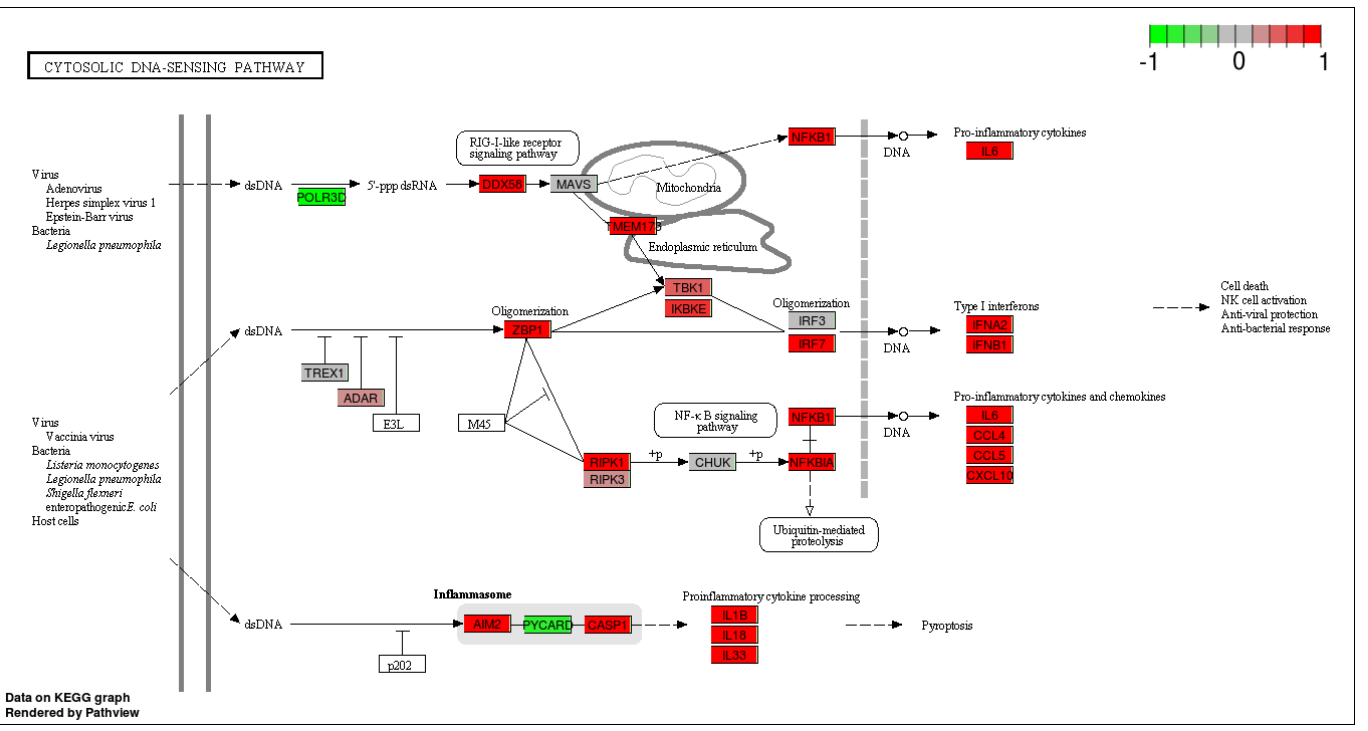




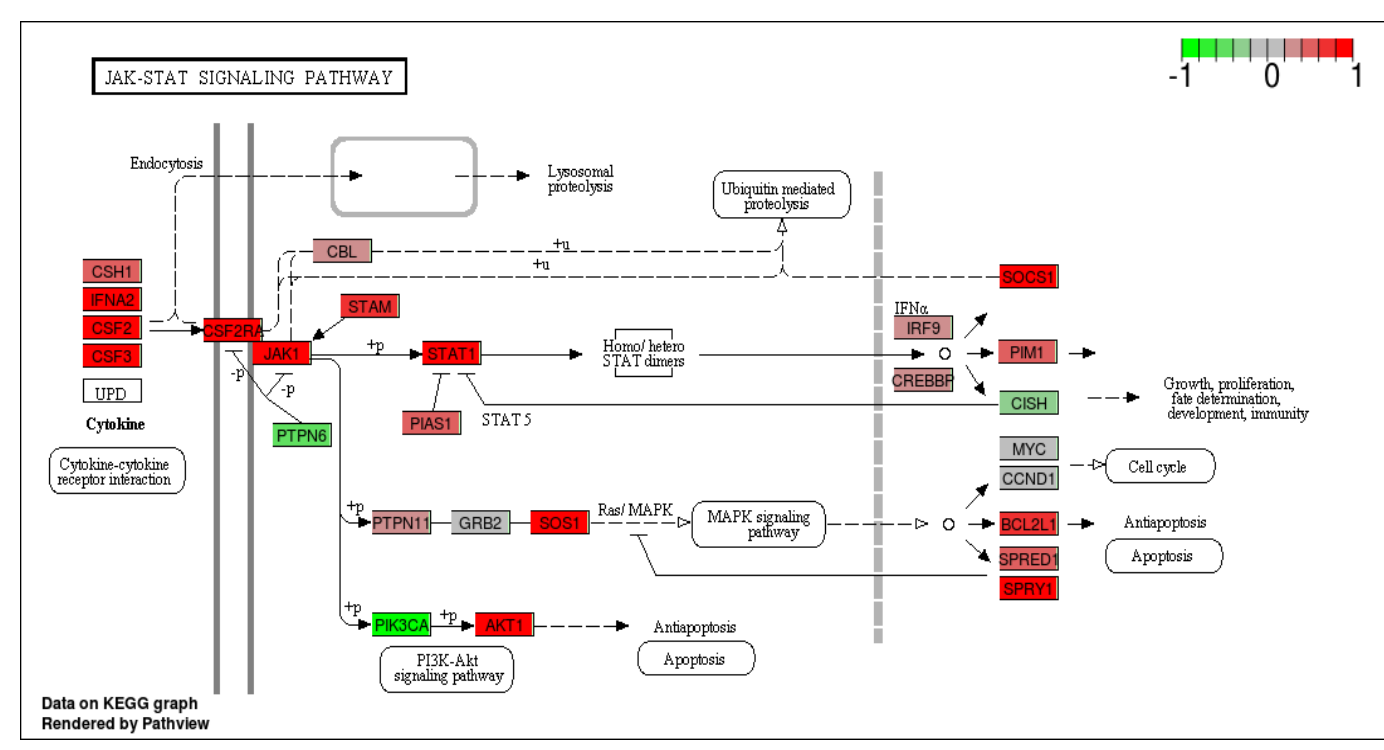

Orientia tsutsugamushi

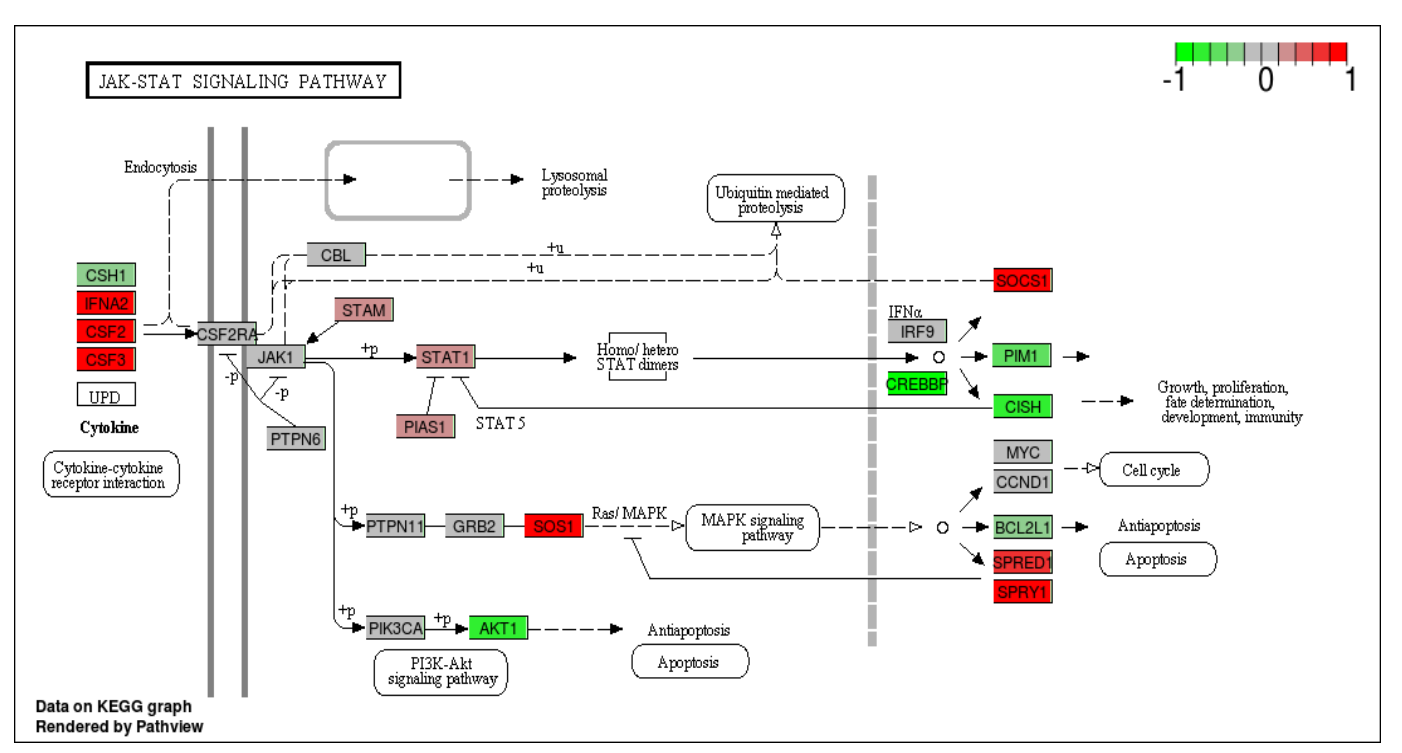

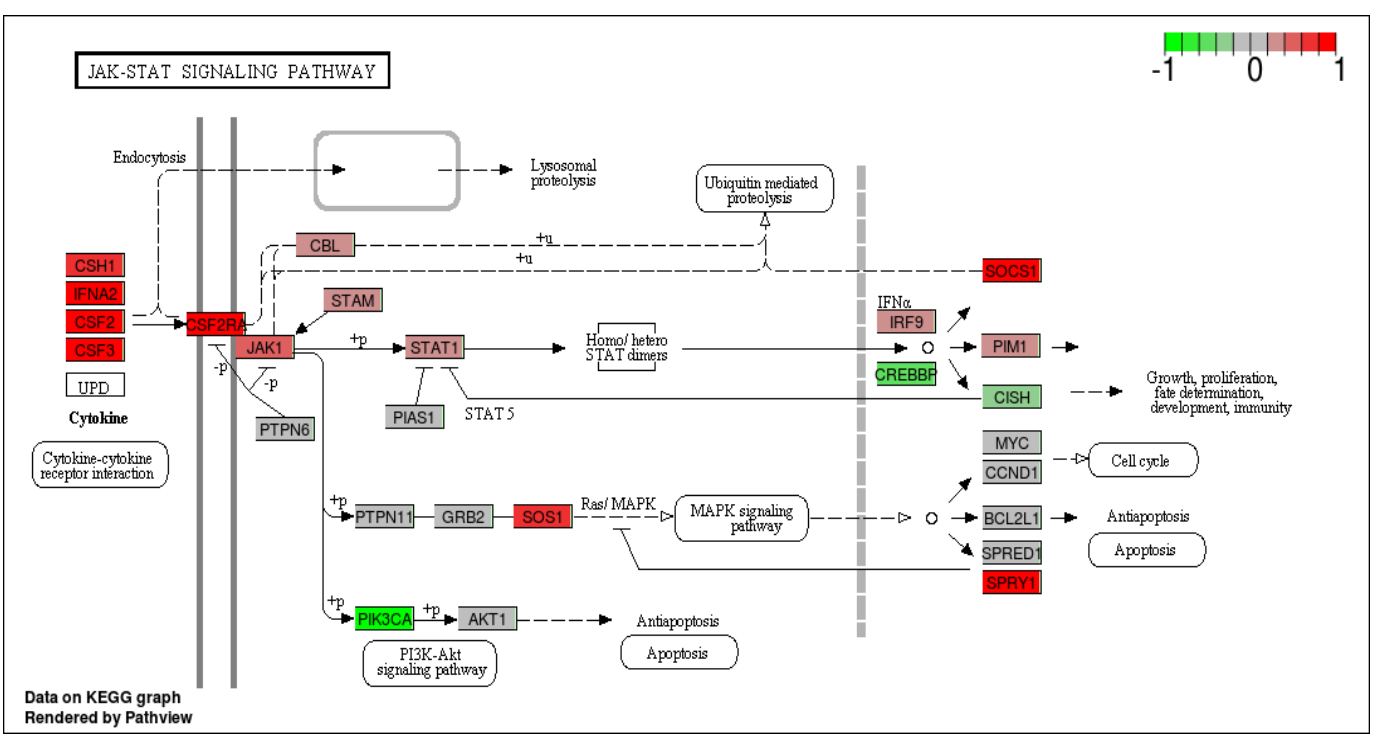

LPS

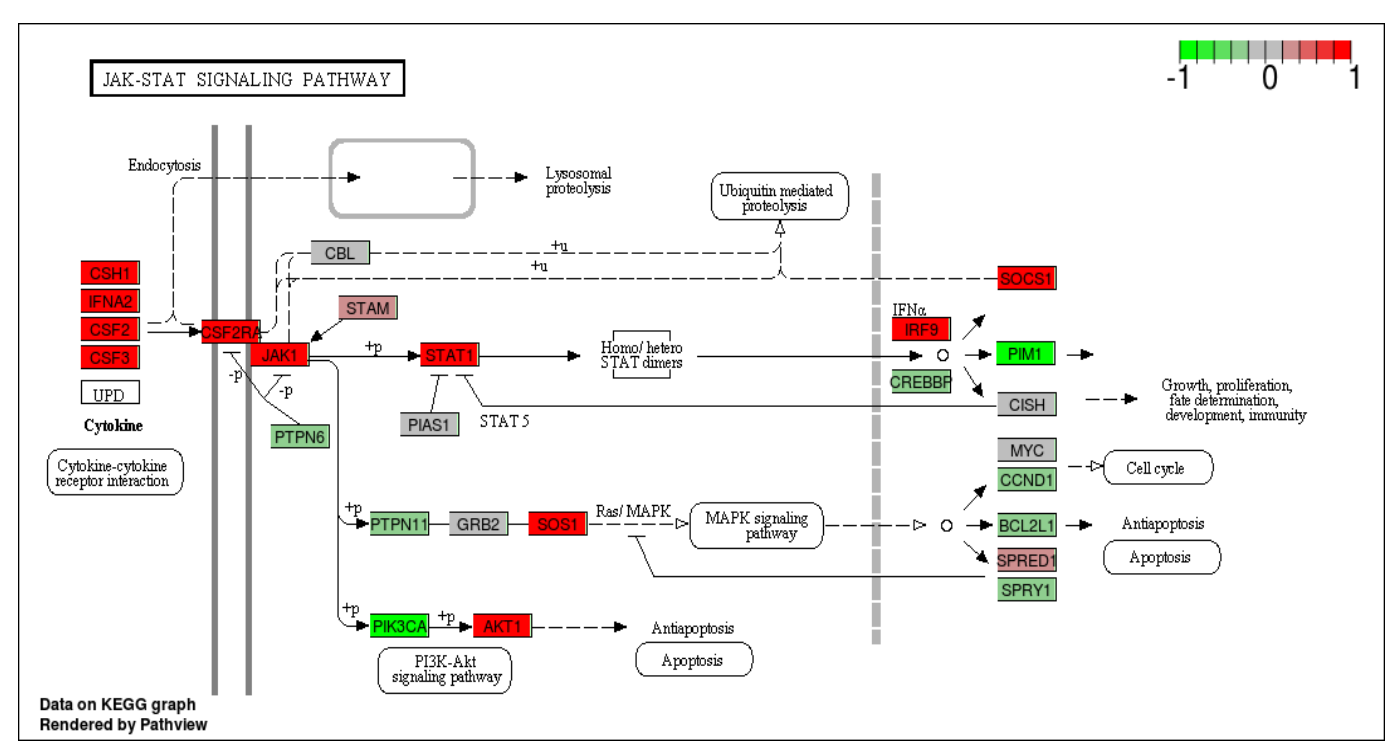



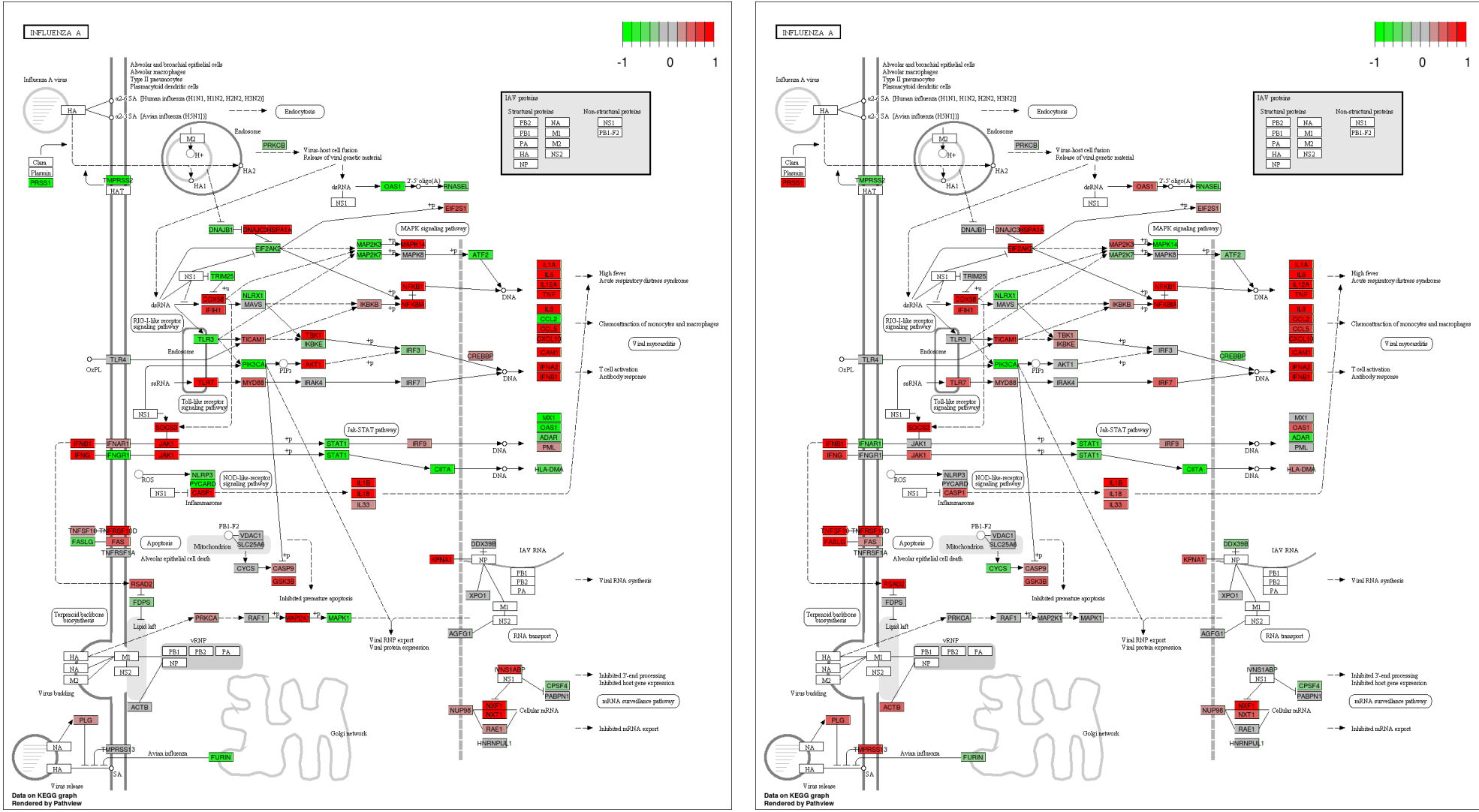

Orientia tsutsugamushi

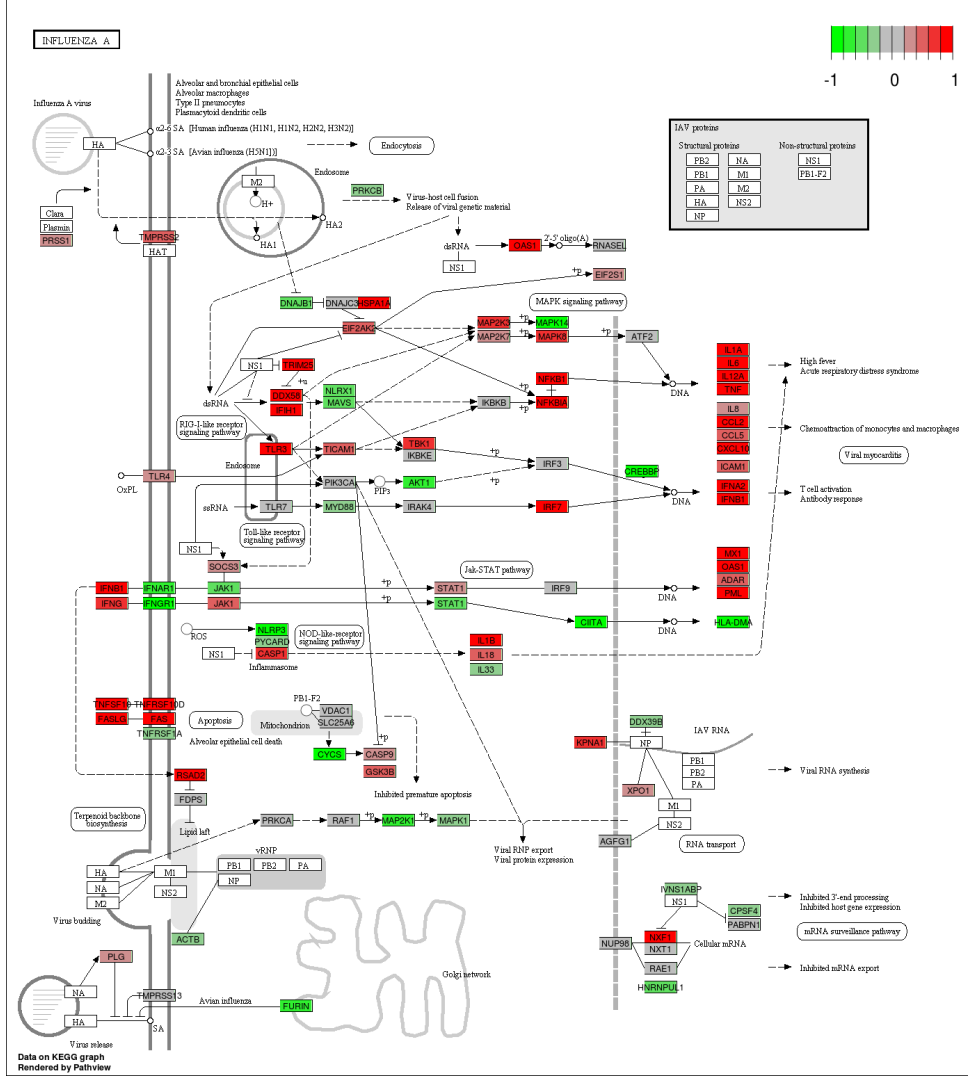

LPS

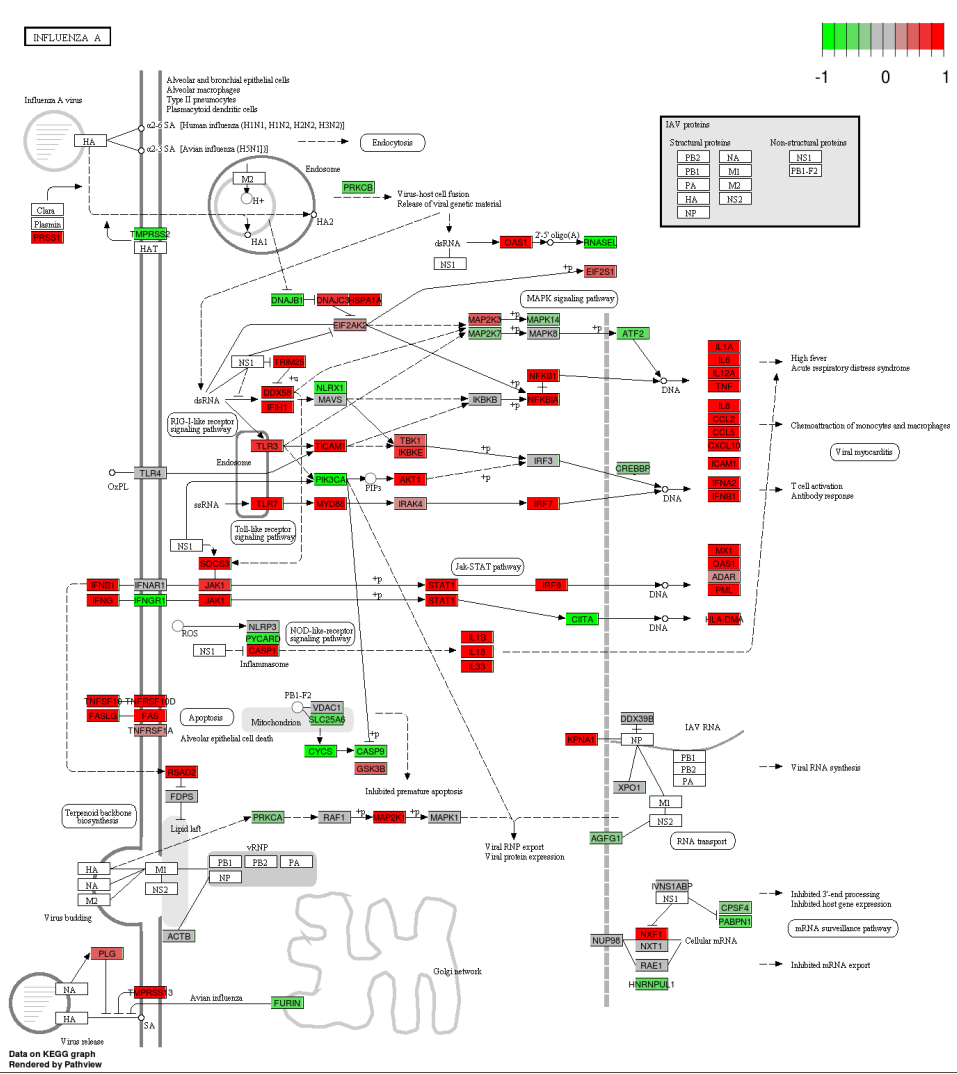




\section{Coxiella burnetii}

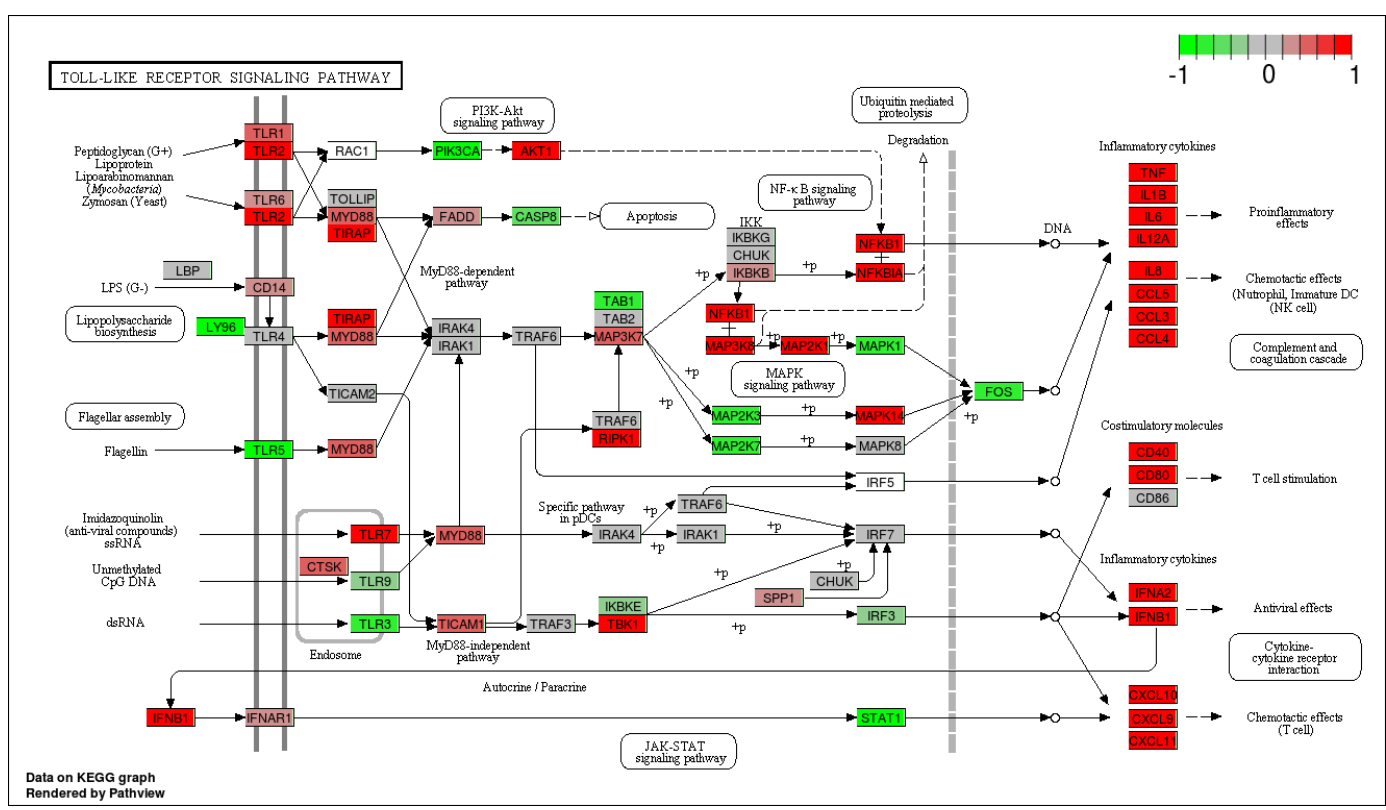

\section{Brucella abortus}

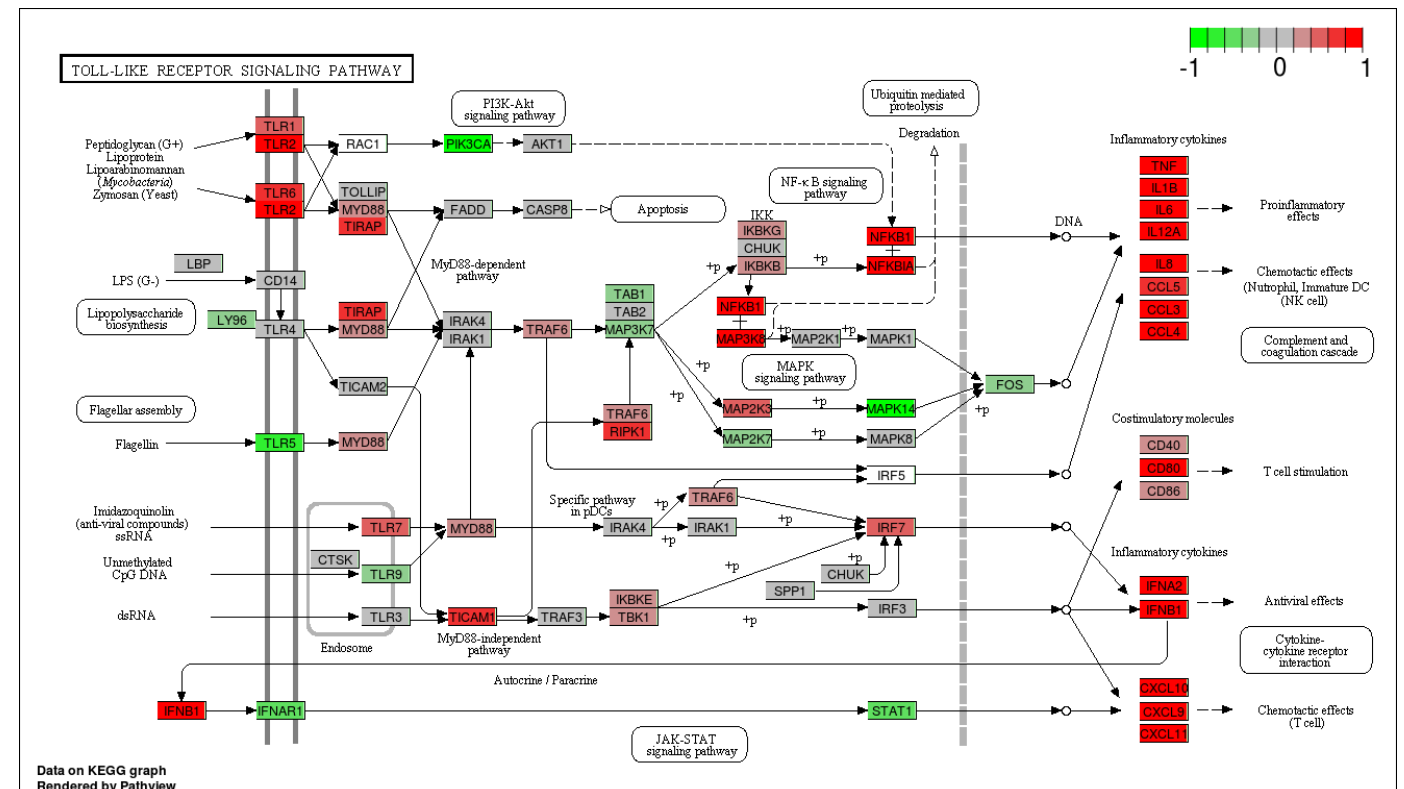

\section{Orientia tsutsugamushi}

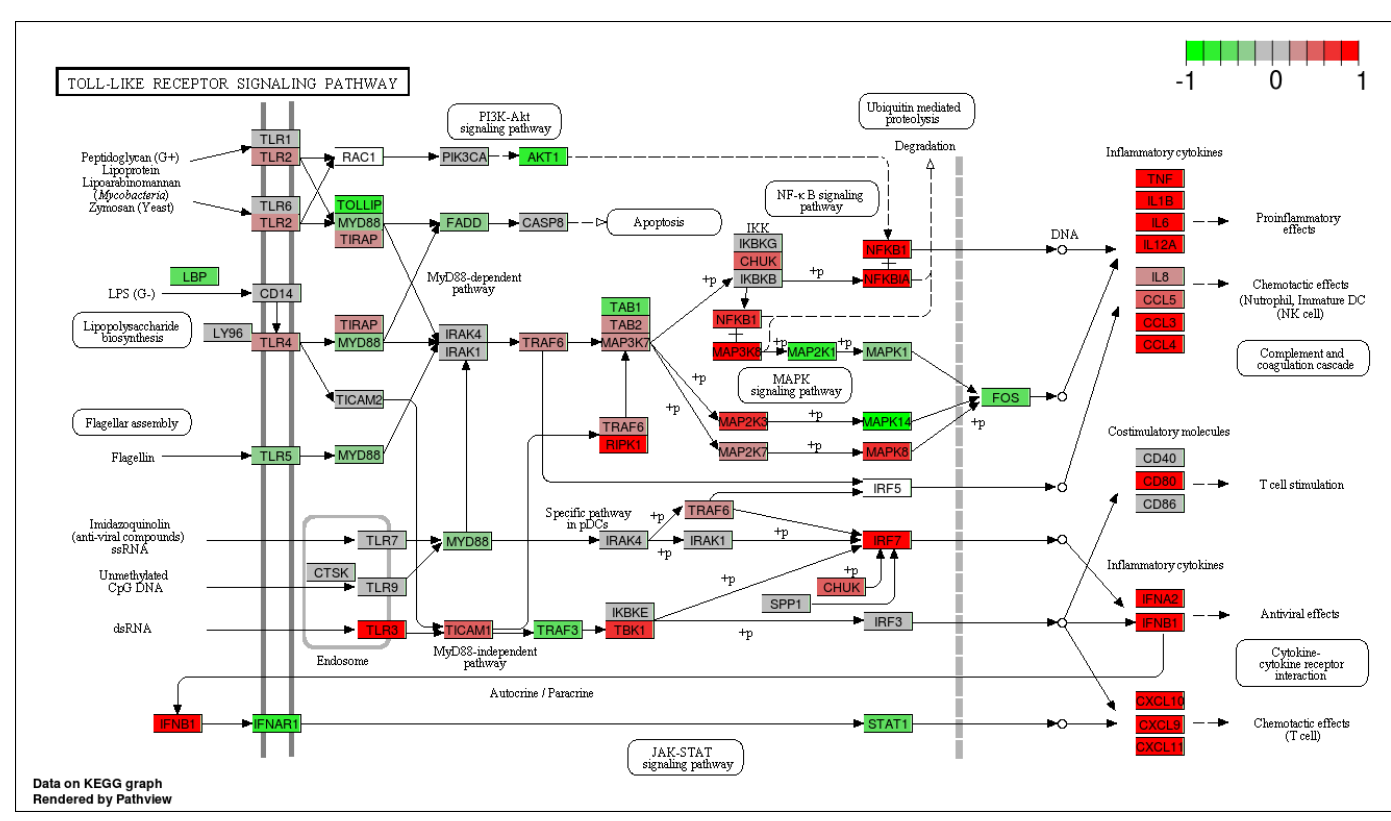

\section{LPS}

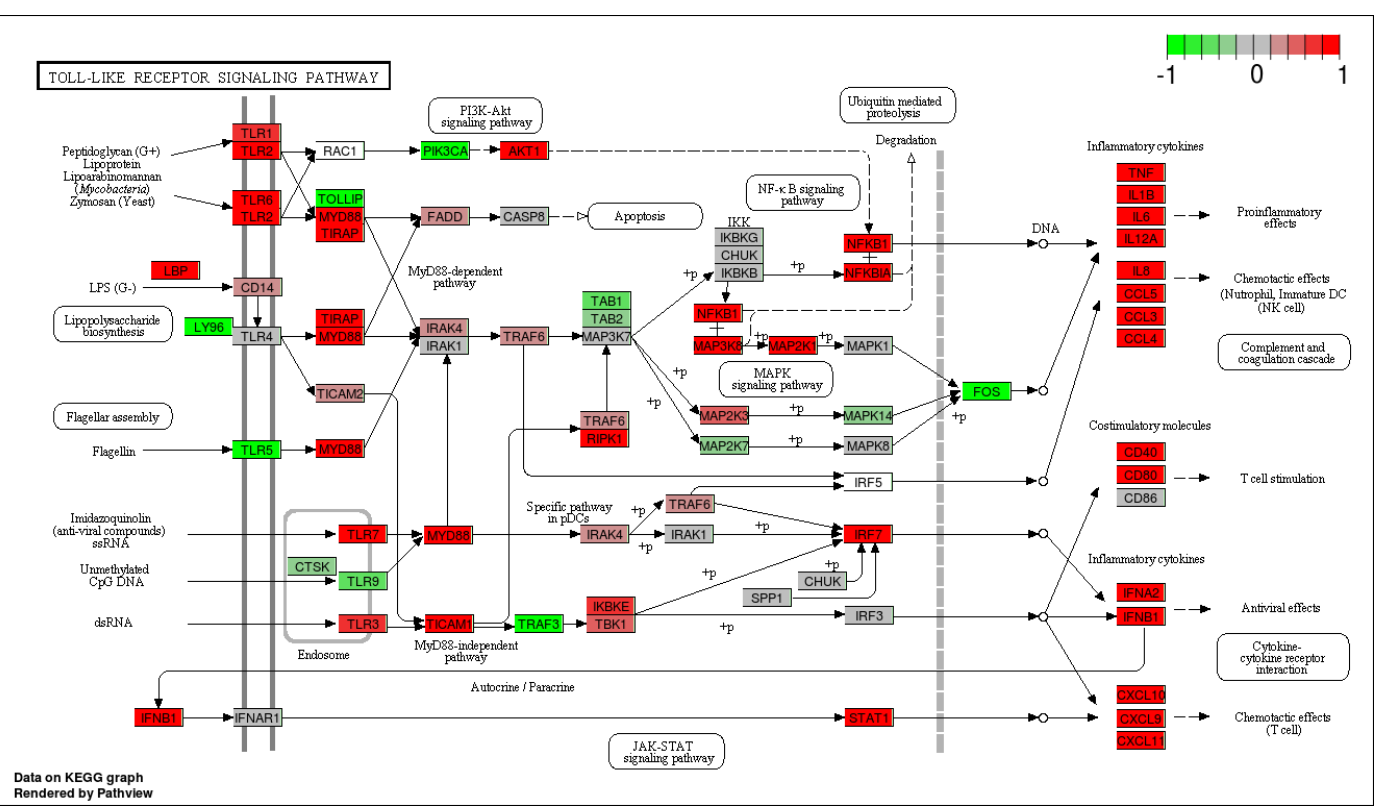




\section{Coxiella burnetii}

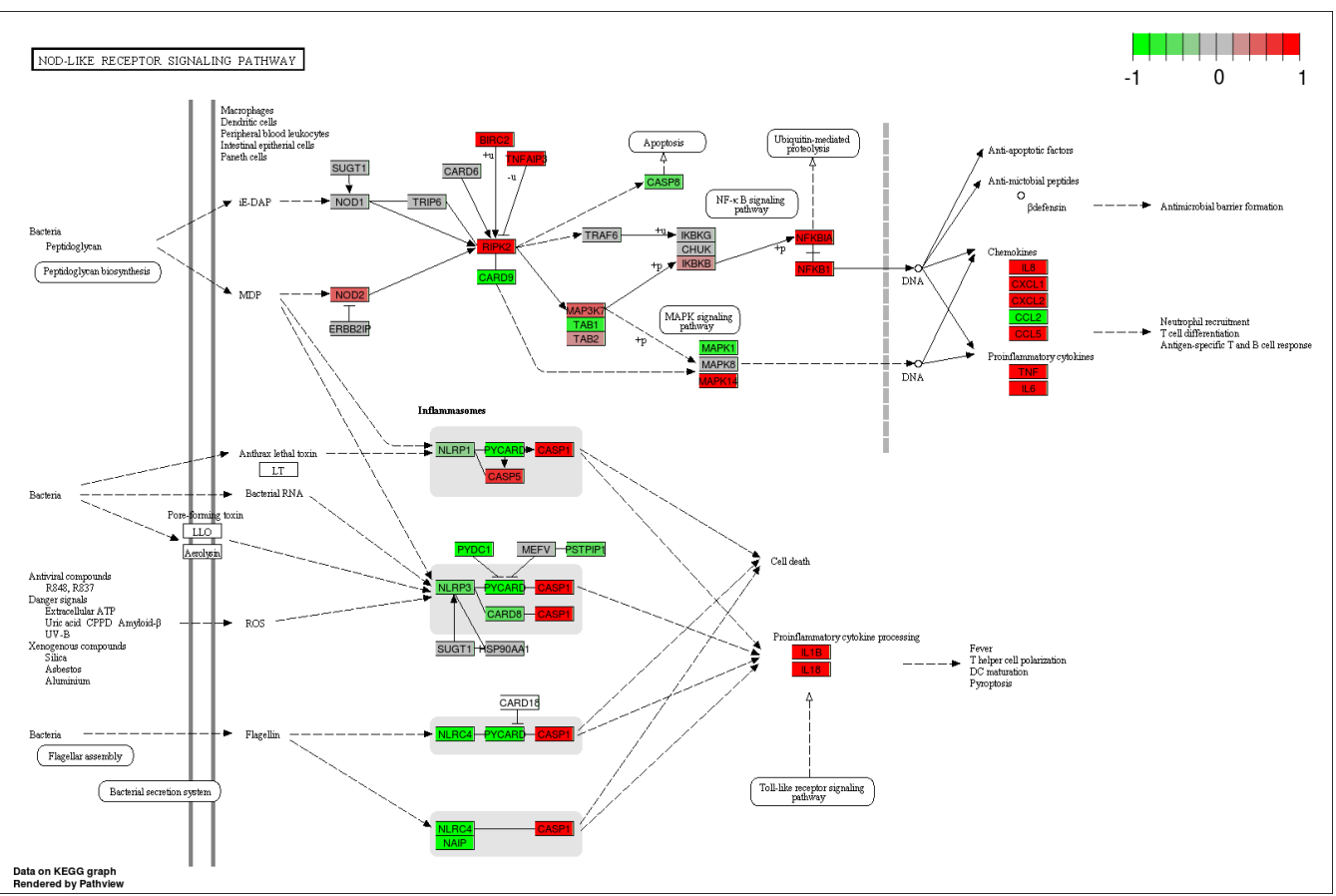

Orientia tsutsugamushi

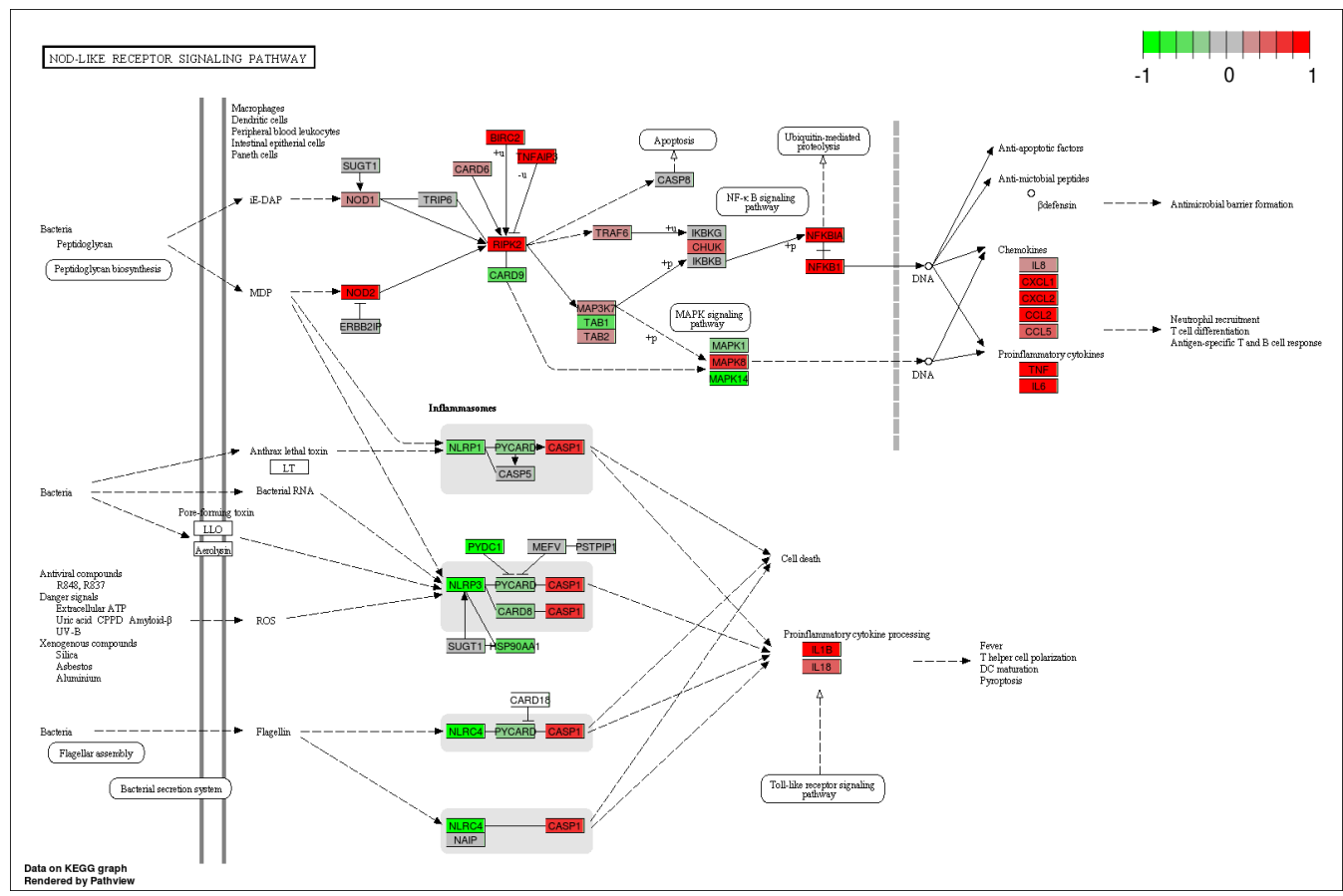

\section{Brucella abortus}

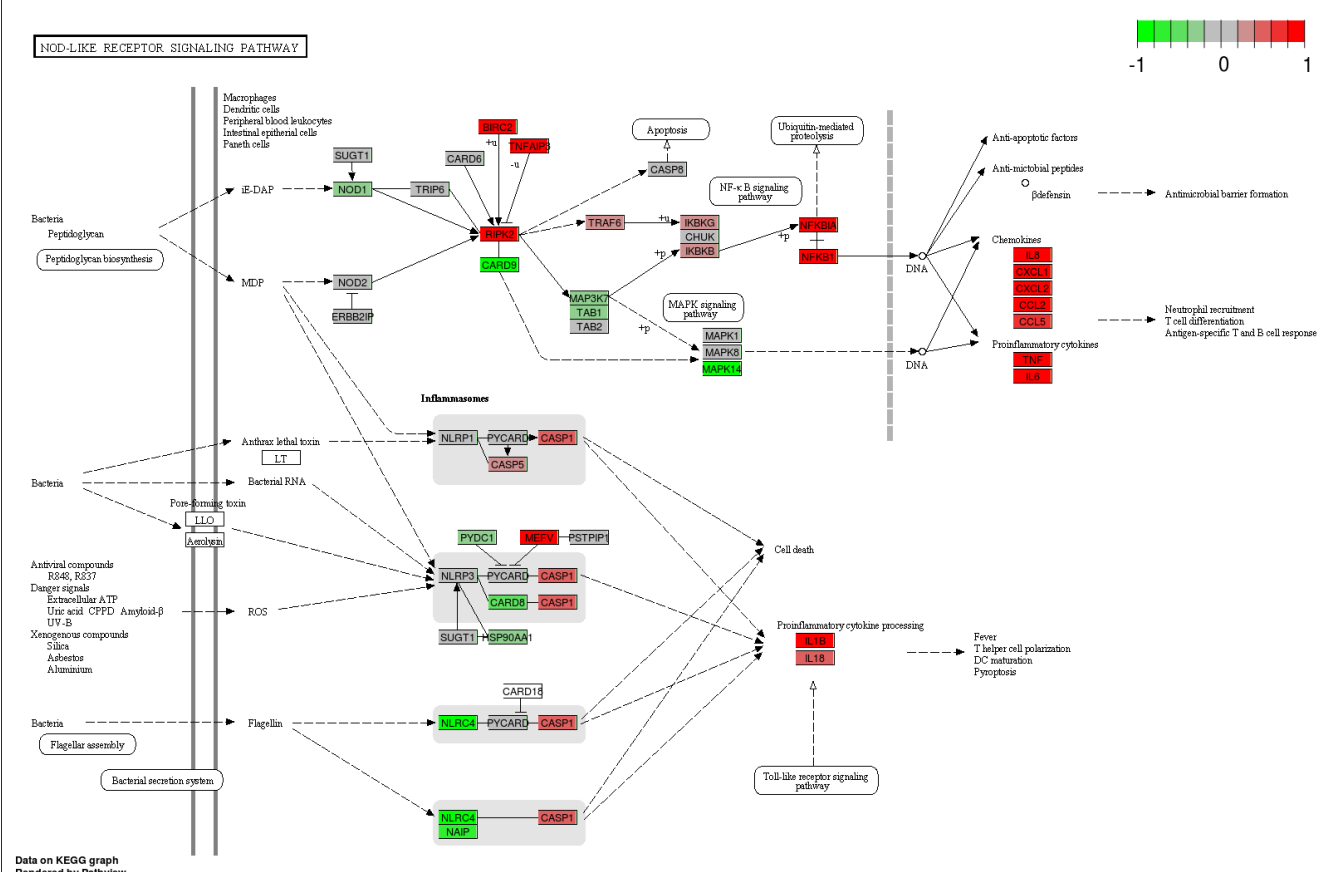

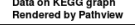

\section{LPS}

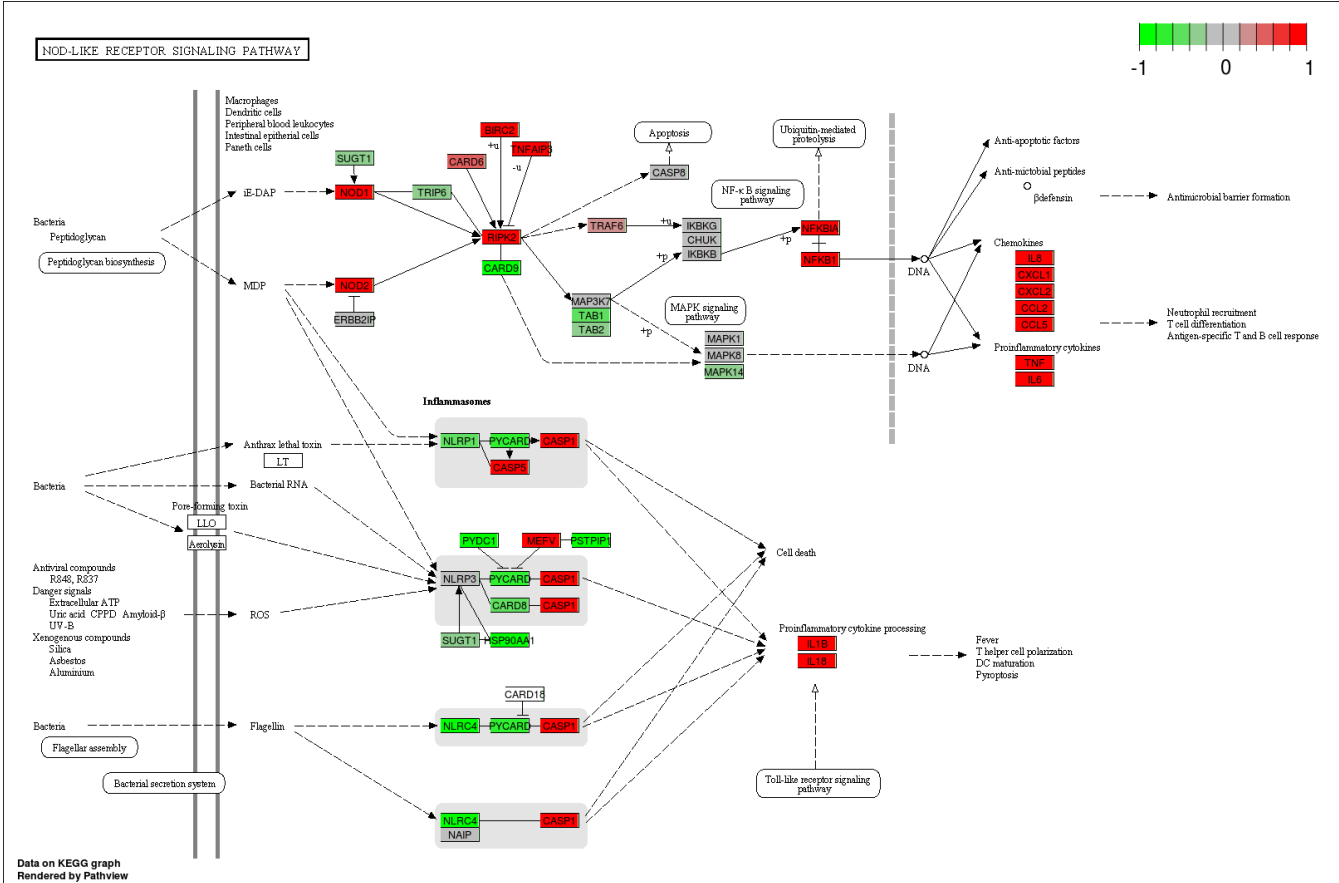


Coxiella burnetii

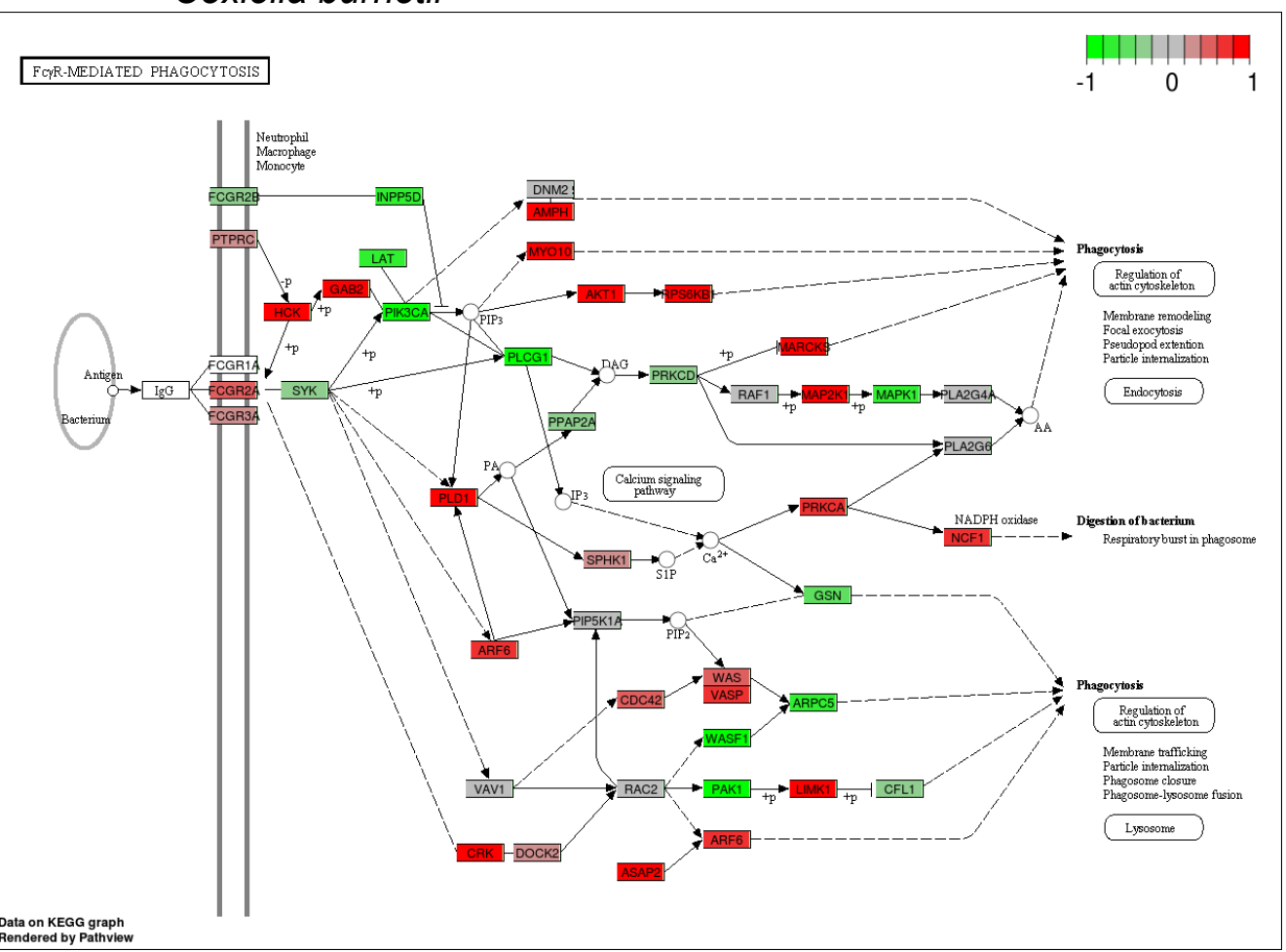

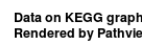

Orientia tsutsugamushi

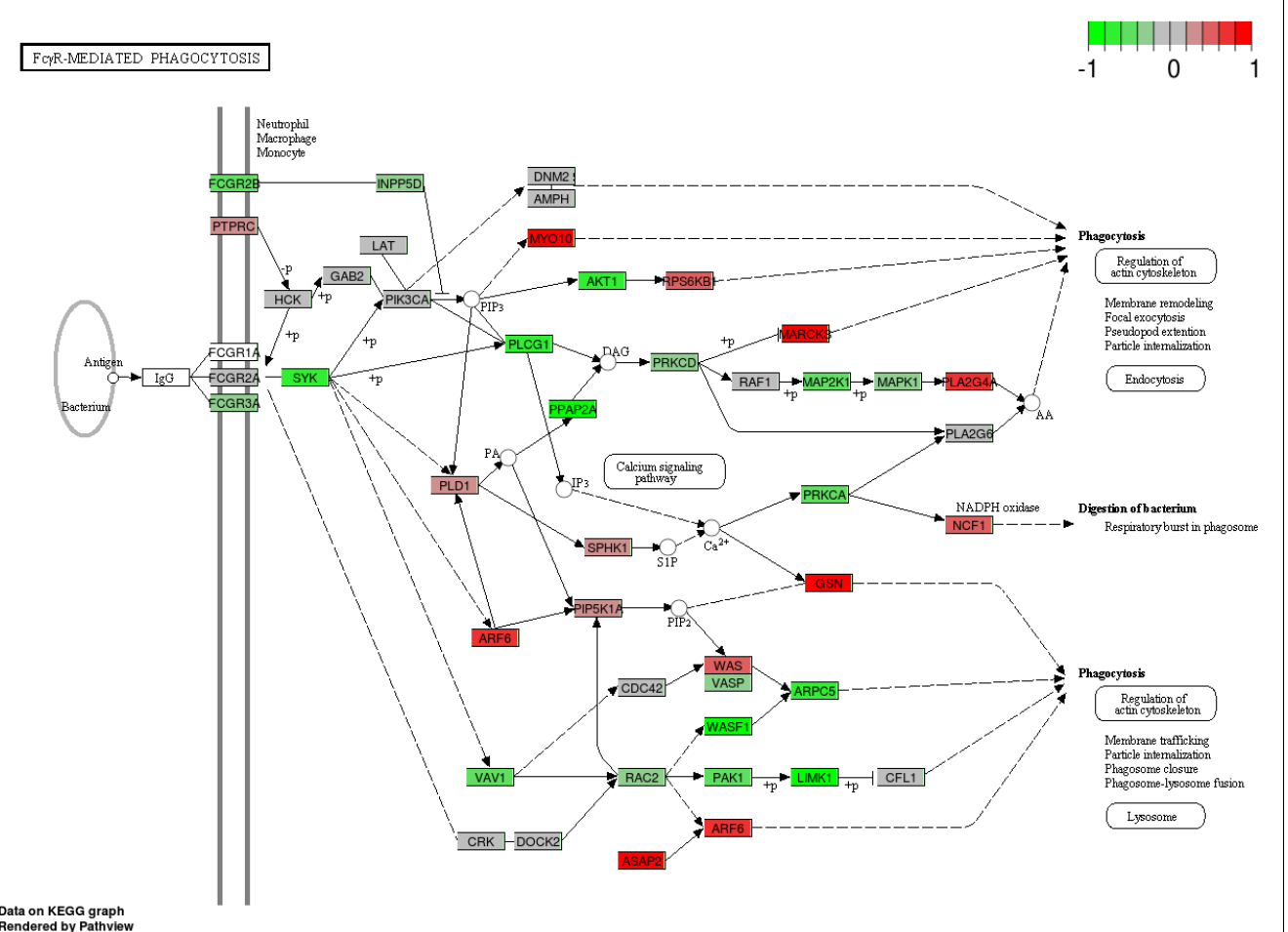

\section{Brucella abortus}

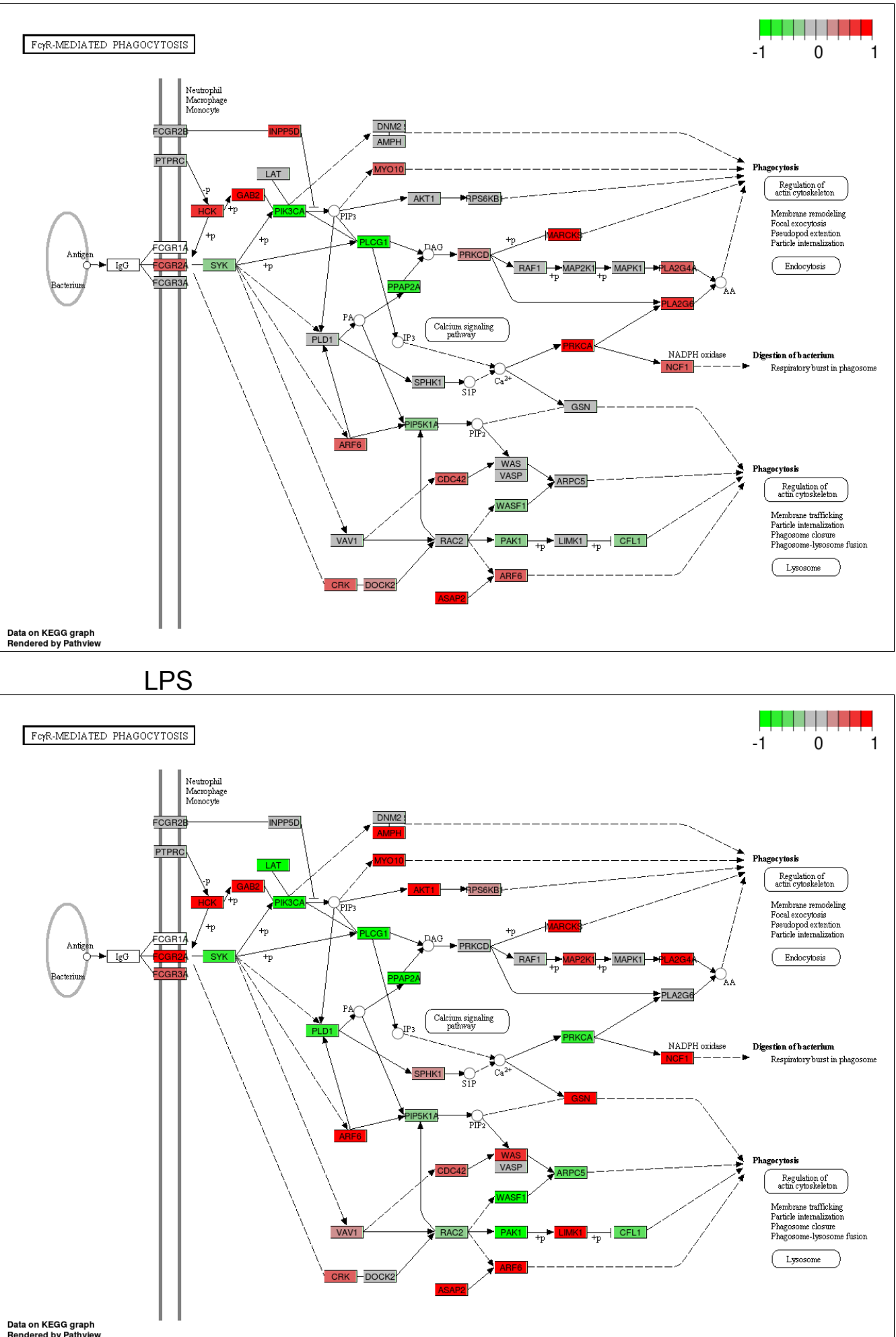

